\title{
Anticancer Half-Sandwich Rhodium(III) Complexes
}

\author{
Klaudia Máliková, Lukáš Masaryk and Pavel Štarha *D \\ Department of Inorganic Chemistry, Faculty of Science, Palacký University in Olomouc, 17, Listopadu 1192/12, \\ 77146 Olomouc, Czech Republic; klaudia.malikova01@upol.cz (K.M.); lukas.masaryk01@upol.cz (L.M.) \\ * Correspondence: pavel.starha@upol.cz; Tel.: +420-585-634-348
}

check for

updates

Citation: Máliková, K.; Masaryk, L.; Štarha, P. Anticancer Half-Sandwich Rhodium(III) Complexes. Inorganics 2021, 9, 26. https://doi.org/10.3390/ inorganics 9040026

Academic Editor: Bruno Therrien

Received: 17 March 2021

Accepted: 4 April 2021

Published: 8 April 2021

Publisher's Note: MDPI stays neutral with regard to jurisdictional claims in published maps and institutional affiliations.

Copyright: (c) 2021 by the authors. Licensee MDPI, Basel, Switzerland. This article is an open access article distributed under the terms and conditions of the Creative Commons Attribution (CC BY) license (https:// creativecommons.org/licenses/by/ $4.0 /)$.

\begin{abstract}
Platinum-based anticancer drugs are most likely the most successful group of bioinorganic compounds. Their apparent disadvantages have led to the development of anticancer compounds of other noble metals, resulting in several ruthenium-based drugs which have entered clinical trials on oncological patients. Besides ruthenium, numerous rhodium complexes have been recently reported as highly potent antiproliferative agents against various human cancer cells, making them potential alternatives to Pt- and Ru-based metallodrugs. In this review, half-sandwich Rh(III) complexes are overviewed. Many representatives show higher in vitro potency than and different mechanisms of action (MoA) from the conventional anticancer metallodrugs (cisplatin in most cases) or clinically studied Ru drug candidates. Furthermore, some of the reviewed Rh(III) arenyl complexes are also anticancer in vivo. Pioneer anticancer organorhodium compounds as well as the recent advances in the field are discussed properly, and adequate attention is paid to their anticancer activity, solution behaviour and various processes connected with their MoA. In summary, this work summarizes the types of compounds and the most important biological results obtained in the field of anticancer half-sandwich Rh complexes.
\end{abstract}

Keywords: rhodium; metal complexes; half-sandwich; anticancer; mechanism of action

\section{Introduction}

Platinum-based drugs (e.g., cisplatin; Figure 1) have been used for the treatment of various types of cancer for more than 40 years [1]. Although this class of anticancer metallodrugs is exceptionally successful, their application is connected with serious side effects and resistance of various tumours $[2,3]$, which incessantly motivates bioinorganic chemists to develop novel biologically active complexes derived not only from platinum [4-6], but also from different d-block elements $[7,8]$. Among them, platinum-group metals other than $\mathrm{Pt}$ are generally accepted as suitable ones for novel anticancer metallodrugs, because a number of $\mathrm{Ru}, \mathrm{Rh}, \mathrm{Pd}, \mathrm{Os}$ and Ir complexes have been reported as being highly effective against various types of cancer cells, and importantly, having higher cancer cell selectivity and acting through different mechanisms of action (MoA) than the mentioned $\mathrm{Pt}(\mathrm{II})$ drugs [9-13].

Regarding the mentioned complexes of the platinum-group metals, Ru complexes NAMI-A [14], IT-139 (originally labelled as KP-1339; Figure 1) [15] and TLD1433 [16] have already entered clinical trials on human oncology patients. These pharmacological successes make Ru one of the hottest d-block metals for bioinorganic and bioorganometallic chemists. One of the main advantages of Ru over Pt is its richer chemistry, offering more structural types to be developed as new drugs for various diseases. Along with the abovementioned octahedral Ru(III) tetrachlorido complexes (NAMI-A, IT-139) and polypyridyl and cyclometalated complexes (TLD1433 and other complexes [17,18]), pseudo-octahedral half-sandwich $\mathrm{Ru}$ (II) complexes have also attracted significant attention as prospective bioactive compounds [7-9,13,18].

In general, half-sandwich complexes have a three-legged piano-stool arrangement with the three legs occupied by either three monodentate ligands or one bidentate and 
one monodentate ligand (with other rare possibilities). It is worth noting that anticancer half-sandwich $\mathrm{Ru}(\mathrm{II})$ complexes have been followed by structurally similar (half-sandwich, $\left.\mathrm{d}^{6}\right) \operatorname{Os}(\mathrm{II})[9,12,13], \mathrm{Rh}(\mathrm{III})$ and $\mathrm{Ir}(\mathrm{III})[10,13]$ ones, also showing high anticancer activity and MoA distinct from Pt drugs.<smiles>N[PH](N)(Cl)Cl</smiles><smiles></smiles>

Figure 1. Structural formulas of the platinum-based drug cisplatin and the anticancer rutheniumbased drug candidate IT-139.

Rhodium is a noble platinum-group metal which is very rare in nature, but the utilisation of Rh (e.g., in catalytic convertors and thermocouples) and its compounds is widespread-e.g., see $[19,20]$. In the field of medicinal chemistry, Rh is used for Rhcatalysed activation towards various bioactive organic compounds [21,22], and as the central atom of various types of bioactive Rh complexes [10,13,23-25]. Besides half-sandwich $\mathrm{Rh}(\mathrm{III})$ complexes (reviewed in this work), highly anticancer polypyridyl [26,27] and bisdimethyl sulfoxido [28] Rh(III) complexes, and Rh(I) N-heterocyclic carbene complexes [29], have to be mentioned in this context as well. Some half-sandwich Rh arenyl complexes have been involved in a couple of reviews (anticancer catalytic [24,25], multi-targeted [13] or multinuclear [23] complexes). Nevertheless, a comprehensive overview discussing their structural types, types of the used ligands, biological activities and MoA is missing in the literature, although such complexes have been intensively studied since the pioneering work of Peruzzini, Dyson and co-workers published in 2006 [30]. In this work, we provide the systematic and topical review of anticancer compounds of this type. The half-sandwich $\mathrm{Rh}$ (III) complexes are categorised according to their nuclearity and type of the ligand used (dentacity, donor atoms). The selected representatives (usually the most active ones) are discussed together with the most important results of their biological analyses.

\section{Mononuclear Complexes}

\subsection{Complexes with Three Monodentate Ligands}

This structural type is in most cases represented by dichlorido complexes of the general formula $\left[\mathrm{Rh}\left(\eta^{5}-\mathrm{Cp}^{\mathrm{x}}\right)(\mathrm{L}) \mathrm{Cl}_{2}\right]^{\mathrm{n}+}$ (Figure 2), meaning that these complexes can be considered as analogues of ruthenium-based RAPTA-type complexes; $\mathrm{Cp}^{\mathrm{x}}$ is cyclopentadienyl or its derivatives, $\mathrm{L}$ is a monodentate ligand and $n=0$ or 1 .
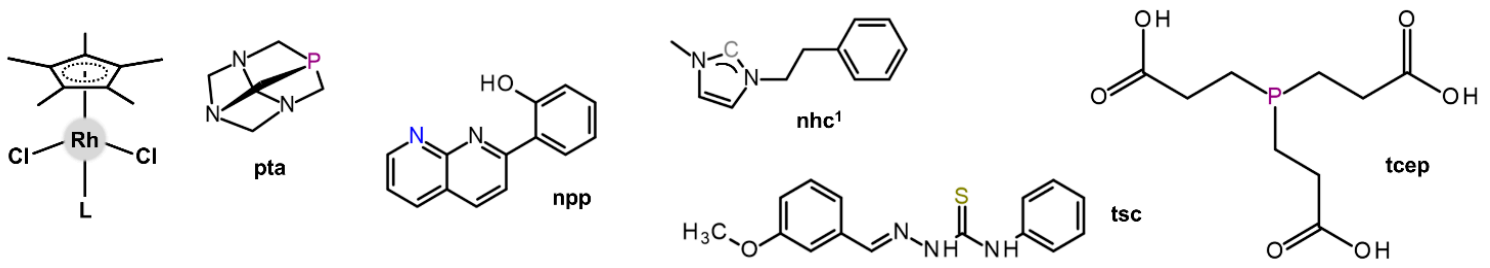

Figure 2. The general structural formula of the $\left[\mathrm{Rh}\left(\eta^{5}-\mathrm{C} \mathrm{p}^{*}\right)(\mathrm{L}) \mathrm{Cl}_{2}\right]$ complexes and structural formulas of selected monodentate L ligands, with the donor atoms given in magenta $(\mathrm{P})$, blue $(\mathrm{N})$, grey $(\mathrm{C})$ or dark yellow $(\mathrm{S})$.

In 2006, the first anticancer $\mathrm{Rh}(\mathrm{III})$ arenyl complex [ $\left.\mathrm{Rh}\left(\eta^{5}-\mathrm{Cp}^{*}\right)(\mathrm{pta}) \mathrm{Cl}_{2}\right]$ (Figure 2, Table 1) was developed as a direct derivative of the (in those days) promising non-platinum, Ru-based drug candidate $\left[\mathrm{Ru}\left(\eta^{6}-\mathrm{pcym}\right)(\mathrm{pta}) \mathrm{Cl}_{2}\right]$ (known as RAPTA-C); pta = 1,3,5-triaza-7- 
phosphaadamantane, $\mathrm{HCp}^{*}=$ pentamethylcyclopentadiene, $\mathrm{pcym}=1$-methyl-4-(propan2-yl)benzene ( $p$-cymene) [30]. The Rh complex exceeded the potency of co-studied compounds RAPTA-C and its Os analogue $\left[\mathrm{Os}\left(\eta^{6}-\mathrm{pcym}\right)(\mathrm{pta}) \mathrm{Cl}_{2}\right]$. Thus, rhodium was introduced to the community as a suitable metal for newly developed half-sandwich anticancer metallodrugs, following the previously reported studies on structurally related ruthenium complexes. Complexes $\left[\mathrm{Rh}\left(\eta^{5}-\mathrm{Cp} \mathrm{p}^{*}\right)(\mathrm{pta})_{2} \mathrm{Cl}\right] \mathrm{Cl}$ and $\left[\mathrm{Rh}\left(\eta^{5}-\mathrm{Cp}^{*}\right)(\mathrm{pta})(\mathrm{CO})\right]$ were found to be less effective than the dichlorido one.

Table 1. In vitro cytotoxicity of $\left[\mathrm{Rh}\left(\eta^{5}-\mathrm{C} \mathrm{p}^{\mathrm{x}}\right)(\mathrm{L}) \mathrm{Cl}_{2}\right]$ and $\left[\mathrm{Rh}\left(\eta^{5}-\mathrm{C} \mathrm{p}^{\mathrm{x}}\right)\left(\mathrm{L}{ }^{\wedge} \mathrm{L}\right) \mathrm{Cl}\right]^{\mathrm{n}+}$ complexes against the selected types of cancer, given together with the results obtained for the non-cancerous (normal) cells. The results are summarised together with the co-studied reference drugs (in parentheses; cisplatin unless stated otherwise), where available. $\mathrm{Cp}^{\mathrm{x}}=$ cyclopentadienyl ligand, $\mathrm{L}=$ a monodentate ligand, $\mathrm{L}^{\wedge} \mathrm{L}=$ a bidentate ligand.

\begin{tabular}{|c|c|c|c|c|c|c|}
\hline Complex & Ovarian $^{a}$ & Lung $^{d}$ & Breast $^{h}$ & Colon $\mathrm{j}$ & Normal $^{m}$ & Ref. \\
\hline$\left[\mathrm{Rh}\left(\eta^{5}-\mathrm{Cp}^{*}\right)(\mathrm{pta}) \mathrm{Cl}_{2}\right]$ & - & 584 & $512^{i}$ & 380 & - & [30] \\
\hline$\left[\mathrm{Rh}\left(\eta^{5}-\mathrm{Cp}^{*}\right)(\right.$ tcep$\left.) \mathrm{Cl}_{2}\right]$ & - & - & $450(65.0)$ & - & - & [31] \\
\hline$\left[\mathrm{Rh}\left(\eta^{5}-\mathrm{Cp}^{*}\right)(\mathrm{npp}) \mathrm{Cl}_{2}\right]$ & - & - & - & $61.3^{\mathrm{k}}(2.8)$ & $>100^{\mathrm{n}}(3.4)$ & [32] \\
\hline$\left[\mathrm{Rh}\left(\eta^{5}-\mathrm{Cp}^{1}\right)(\mathrm{py}) \mathrm{Cl}_{2}\right]$ & - & - & - & $132.0(2.5)$ & - & [33] \\
\hline$\left[\mathrm{Rh}\left(\eta^{5}-\mathrm{Cp}^{*}\right)\left(\mathrm{nhc}^{1}\right) \mathrm{Cl}_{2}\right]$ & $5.6(1.3)$ & - & $65.0(1.5)$ & $>100(1.5)$ & $87.0^{\circ}(8.5)$ & [34] \\
\hline$\left[\mathrm{Rh}\left(\eta^{5}-\mathrm{Cp}^{*}\right)\left(\mathrm{nhc}^{2}\right) \mathrm{Cl}_{2}\right]$ & - & $23.0^{\mathrm{e}}$ & - & $11.0^{\mathrm{k}}$ & - & [35] \\
\hline$\left[\mathrm{Rh}\left(\eta^{5}-\mathrm{Cp}^{*}\right)(\mathrm{dppn}) \mathrm{Cl}\right] \mathrm{CF}_{3} \mathrm{SO}_{3}$ & - & - & $0.8(2.0)$ & $3.2(7.0)$ & - & {$[36]$} \\
\hline$\left[\mathrm{Rh}\left(\eta^{5}-\mathrm{Cp}^{*}\right)(\mathrm{dppz}) \mathrm{Cl}\right] \mathrm{CF}_{3} \mathrm{SO}_{3}$ & - & - & $1.5(2.0)$ & $4.3(7.0)$ & 2.8 & {$[36,37]$} \\
\hline$\left[\mathrm{Rh}\left(\eta^{5}-\mathrm{Cp}^{*}\right)(\mathrm{phen}) \mathrm{Cl}\right] \mathrm{CF}_{3} \mathrm{SO}_{3}$ & - & - & 4.7 & 8.0 & - & [37] \\
\hline$\left[\mathrm{Rh}\left(\eta^{5}-\mathrm{Cp}^{*}\right)(\mathrm{phen}) \mathrm{Cl}\right] \mathrm{PF}_{6}$ & 17.8 & - & - & - & - & {$[38]$} \\
\hline$\left[\mathrm{Rh}\left(\eta^{5}-\mathrm{Cp}^{*}\right)(\right.$ phen-SAHA $\left.) \mathrm{Cl}\right] \mathrm{Cl}$ & - & $4.1^{\mathrm{e}}$ & - & - & - & {$[39]$} \\
\hline$\left[\mathrm{Rh}\left(\eta^{5}-\mathrm{Cp}^{*}\right)\left(\mathrm{bzhy}^{\mathrm{OH}}\right) \mathrm{Cl}\right] \mathrm{PF}_{6}$ & - & - & - & $2.0^{\mathrm{k}}(3.5)$ & $>100^{\mathrm{n}}(3.4)$ & {$[40]$} \\
\hline$\left[\mathrm{Rh}\left(\eta^{5}-\mathrm{Cp}^{*}\right) \mathrm{Cl}(\right.$ pyin $\left.)\right]$ & $13.0(10.3)$ & - & - & - & $34.7^{\circ}(43.0)$ & {$[41]$} \\
\hline$\left[\mathrm{Rh}\left(\eta^{5}-\mathrm{Cp}^{*}\right) \mathrm{Cl}(\mathrm{lap})\right]$ & $7.3^{\mathrm{b}}(0.1)$ & $91.0(1.3)$ & - & $93.0^{\mathrm{k}}(2.7)$ & - & {$[42]$} \\
\hline$\left[\mathrm{Rh}\left(\eta^{5}-\mathrm{Cp}^{*}\right) \mathrm{Cl}(\mathrm{cur})\right]$ & 14.9 & - & - & - & 13.7 & {$[43]$} \\
\hline$\left[\mathrm{Rh}\left(\eta^{5}-\mathrm{Cp}^{*}\right) \mathrm{Cl}(\mathrm{fla})\right]$ & $3.1^{\mathrm{b}}$ & 15.0 & - & $7.9^{1}$ & - & {$[44]$} \\
\hline$\left[\mathrm{Rh}\left(\eta^{5}-\mathrm{Cp}^{*}\right)\left(\mathrm{pytsc}^{1}\right) \mathrm{Cl}\right] \mathrm{Cl}$ & - & $5.1(1.8)^{f}$ & $13.5(2.8)^{f}$ & - & $166.5(0.5)^{f}$ & {$[45]$} \\
\hline$\left[\mathrm{Rh}\left(\eta^{5}-\mathrm{Cp}^{*}\right)(\mathrm{pbtu}) \mathrm{Cl}\right] \mathrm{Cl}$ & - & - & - & $9.7(2.8)$ & $19.5^{\mathrm{n}}(3.4)$ & {$[46]$} \\
\hline$\left[\mathrm{Rh}\left(\eta^{5}-\mathrm{Cp}^{*}\right)(\mathrm{bzit}) \mathrm{Cl}\right] \mathrm{PF}_{6}$ & - & $>100$ & - & $76.0^{\mathrm{k}}$ & - & [47] \\
\hline$\left[\mathrm{Rh}\left(\eta^{5}-\mathrm{Cp}^{*}\right)(\right.$ atpy $\left.) \mathrm{Cl}\right]$ & $0.8^{b}(50.0)^{c}$ & $3.8(156)^{c}$ & - & $1.0^{1}(62.0)^{c}$ & - & {$[48]$} \\
\hline$\left[\mathrm{Rh}\left(\eta^{5}-\mathrm{Cp}^{*}\right) \mathrm{Cl}(\mathrm{thma})\right]$ & $1.0^{\mathrm{b}}(0.2)$ & $5.9(1.3)$ & - & $1.0^{1}(3.5)$ & - & [49] \\
\hline$\left[\mathrm{Rh}\left(\eta^{5}-\mathrm{Cp}^{*}\right) \mathrm{Cl}(\mathrm{thpy})\right]$ & $0.4^{\mathrm{b}}(0.2)$ & $0.7(1.3)$ & - & $0.3^{1}(3.5)$ & - & {$[50]$} \\
\hline$\left[\mathrm{Rh}\left(\eta^{5}-\mathrm{Cp}^{*}\right) \mathrm{Cl}\left(\mathrm{sepy}^{1}\right)\right]$ & $25.0^{\mathrm{b}}(0.2)$ & $99.0(1.3)$ & - & $27.0^{1}(3.5)$ & - & {$[51]$} \\
\hline$\left[\mathrm{Rh}\left(\eta^{5}-\mathrm{Cp}^{*}\right) \mathrm{Cl}\left(\mathrm{ppy}^{1}\right)\right]$ & $6.0(1.4)$ & - & $9.9^{\mathrm{i}}(60.0)$ & - & - & {$[52]$} \\
\hline$\left[\mathrm{Rh}\left(\eta^{5}-\mathrm{Cp}^{*}\right)(\mathrm{bpt}) \mathrm{Cl}\right]$ & - & $6.0(4.7)^{g}$ & - & - & - & {$[53]$} \\
\hline$\left[\mathrm{Rh}\left(\eta^{5}-\mathrm{Cp}^{*}\right) \mathrm{Cl}(\mathrm{pbim})\right]$ & $7.1(1.5)$ & - & $6.4^{\mathrm{i}}(38.0)$ & $7.8(9.5)$ & - & {$[54]$} \\
\hline$\left[\mathrm{Rh}\left(\eta^{5}-\mathrm{Cp}^{*}\right) \mathrm{Cl}(\mathrm{pma})\right]$ & - & $8.0(20.0)$ & - & - & - & {$[55]$} \\
\hline$\left[\mathrm{Rh}\left(\eta^{5}-\mathrm{Cp}^{\mathrm{bph}}\right)(\mathrm{bqui}) \mathrm{Cl}\right]$ & $1.6(1.0)$ & $7.7(3.8)$ & - & - & - & {$[56]$} \\
\hline
\end{tabular}

${ }^{a}$ A2780 ovarian carcinoma (unless stated otherwise); ${ }^{\mathrm{b}} \mathrm{CH} 1 / \mathrm{PA}-1$ ovarian carcinoma; ${ }^{\mathrm{c}}$ IT-139 was used as the reference drug; ${ }^{\mathrm{d}}$ A549 lung carcinoma (unless stated otherwise); ${ }^{\mathrm{e}} \mathrm{NCI}-\mathrm{H} 460$ lung carcinoma; ${ }^{\mathrm{f}}$ doxorubicin was used as the reference drug; ${ }^{\mathrm{g}}$ auranofin was used as the reference drug; ${ }^{\mathrm{h}}$ MCF-7 breast adenocarcinoma (unless stated otherwise); ${ }^{\mathrm{i}}$ T47D breast carcinoma; ${ }^{\mathrm{j}}$ HT-29 colorectal adenocarcinoma (unless stated otherwise); ${ }^{k}$ HCT-116 colorectal carcinoma; ${ }^{1}$ SW480 colorectal adenocarcinoma; ${ }^{\mathrm{m}}$ HEK-293 embryonic kidney epithelial

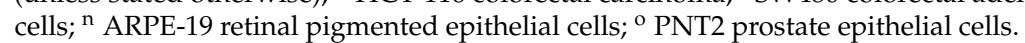


The following study showed complex $\left[\mathrm{Rh}\left(\eta^{5}-\mathrm{Cp} \mathrm{p}^{*}\right)(\mathrm{pta}) \mathrm{Cl}_{2}\right]$ as ineffective at inhibiting cathepsin B in vitro, which corresponds with the use of its Ir analogue, but differs from effective cathepsin B inhibitors RAPTA-C, its Os congener and NAMI-A [57]. More recently, another structurally similar dichlorido $\mathrm{Rh}$ complex, $\left[\mathrm{Rh}\left(\eta^{5}-\mathrm{C} \mathrm{p}^{*}\right)(\mathrm{tcep}) \mathrm{Cl}_{2}\right]$, showed comparable potency with cisplatin in the MDA-MB-231 triple-negative breast cancer cell line, where, however, this Rh complex was ca one order of magnitude less effective than its Ir counterpart; tcep = tris(2-carboxyethyl)phosphine (Figure 2, Table 1) [31].

Following the pioneering organorhodium complex $\left[\mathrm{Rh}\left(\eta^{5}-\mathrm{Cp}^{*}\right)(\mathrm{pta}) \mathrm{Cl}_{2}\right]$, several dichlorido complexes of this structural type containing a monodentate $N$-donor ligand have been reported, but these complexes were less potent in vitro than the clinically used cisplatin $[32,33,58,59]$. Among these complexes, $\left[\mathrm{Rh}\left(\eta^{5}-\mathrm{Cp} \mathrm{p}^{*}\right)(\mathrm{npp}) \mathrm{Cl}_{2}\right]$ (Figure 2, Table 1) exhibited higher activity on the MIA-PaCa-2 (pancreatic carcinoma) cells than the Ru and Ir analogues; npp = 2-(1,8-naphthyridin-2-yl)phenol [32]. Additionally, of interest, complex $\left[\mathrm{Rh}\left(\eta^{5}-\mathrm{Cp}^{1}\right)(\mathrm{py}) \mathrm{Cl}_{2}\right]$ (Table 1$)$ acted as a potent inhibitor of thioredoxin reductase (TrxR); $\mathrm{HCp}^{1}=$ 5-(2,3,4,5-tetramethylcyclopenta-2,4-dien-1-yl)pentan-1-ol, py = pyridine [33].

In contrast to complexes with $\mathrm{N}$-donor ligands, dichlorido-Rh-arenyl complexes with monodentate $C$-donor carbene ligands have showed more pronounced anticancer activities. Still, complex $\left[\mathrm{Rh}\left(\eta^{5}-\mathrm{Cp}^{*}\right)\left(\mathrm{nhc}^{1}\right) \mathrm{Cl}_{2}\right]$ (Figure 2$)$ was markedly less cytotoxic than cisplatin in, e.g., the A2780 (ovarian) and MCF-7 (breast) carcinoma cells (Table 1), although its activity was higher than determined for its Ru analogue; $n c^{1}=1$-methyl-3-(2-phenylethyl)-2,3dihydro- $1 \mathrm{H}$-imidazole [34]. Another complex of this type, $\left[\mathrm{Rh}\left(\eta^{5}-\mathrm{Cp}^{*}\right)\left(\mathrm{nh}^{2}\right) \mathrm{Cl}_{2}\right]$, showed moderate cytotoxicity $\left(\mathrm{IC}_{50}=11-23 \mu \mathrm{M}\right.$; Table 1$)$ connected with extraordinary inhibition of TrxR; nhc $^{2}=1,3$-dibenzyl-2,3-dihydro- $1 H$-benzimidazole [35].

Other complexes [60-62], such as $\left[\mathrm{Rh}\left(\eta^{5}-\mathrm{Cp}^{*}\right)(\mathrm{tsc}) \mathrm{Cl}_{2}\right]$ (Figure 2) [60], contain a monodentate $S$-donor thiosemicarbazone; tsc $=(2 E)$-2-[(3-methoxyphenyl)methylidene $]-N$ phenylhydrazine-1-carbothioamide. Complex $\left[\mathrm{Rh}\left(\eta^{5}-\mathrm{Cp}^{*}\right)(\mathrm{tsc}) \mathrm{Cl}_{2}\right]$ was more cytotoxic than cisplatin in some of the human cell lines used (HeLa cervical and SGC-7901 gastric carcinomas), and importantly, showed remarkable cytoselectivity, since it was significantly less active in the normal HEK-293 cells (human embryonic kidney) than cisplatin. Complexes with structurally similar thiourea-based ligands achieved lower activity than cisplatin, and in most cases also than their co-studied Ru and Ir analogues [61,62].

\subsection{Complexes with Bidentate and Monodentate Ligands}

\subsubsection{Chlorido Complexes}

This broad family of organorhodium complexes is herein categorised according to the donor set of the bidentate (chelating) ligand.

Complexes with $N, N$-ligands. In 2008, Sheldrick and co-workers studied a pioneering series of organorhodium complexes-in particular, polypyridyl (pp) complexes of the general formula $\left[\mathrm{Rh}\left(\eta^{5}-\mathrm{Cp}^{*}\right)(\mathrm{pp}) \mathrm{Cl}\right] \mathrm{CF}_{3} \mathrm{SO}_{3}$ and analogues with an $S$-donor ligand instead of $\mathrm{Cl}^{-}$(see Section 2.2.2), and observed that most of them were cytotoxic towards the human MCF-7 breast and HT-29 colon cancer cell lines $\left(\mathrm{IC}_{50}=0.6-10.7 \mu \mathrm{M}\right)$ [36]. The cytotoxicity was dependent on the size of the polypyridyl ligand, with $\mathrm{IC}_{50}$ values decreasing in the order dpq $>d p p z>d p p n$, where dpq = dipyrido- $\left[3,2-f: 2^{\prime}, 3^{\prime}-h\right]$ quinoxaline,

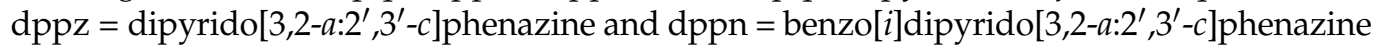
(Figure 3, Table 1). The following series with methyl-substituted pp ligands revealed significant improvements in their antiproliferative activity [37]. For example, the $\mathrm{IC}_{50}$ value towards the HT-29 cells decreased from $4.3 \mu \mathrm{M}$ (dppz complex) to $1.0 \mu \mathrm{M}$ for the complex with a methylated dppz ligand. The same trend was observed for 1,10-phenantroline (phen) and its variously substituted derivatives, which were found to be markedly more cytotoxic than the Ir analogues $[37,63]$. In contrast, the Rh complex with a carboxylated dppz ligand was inactive. Additionally, all the tested phen- and dppz-based organorhodium complexes showed poor selectivity towards the cancer cells (MCF-7, HT-29) over the normal ones (HEK-293) (Table 1). 


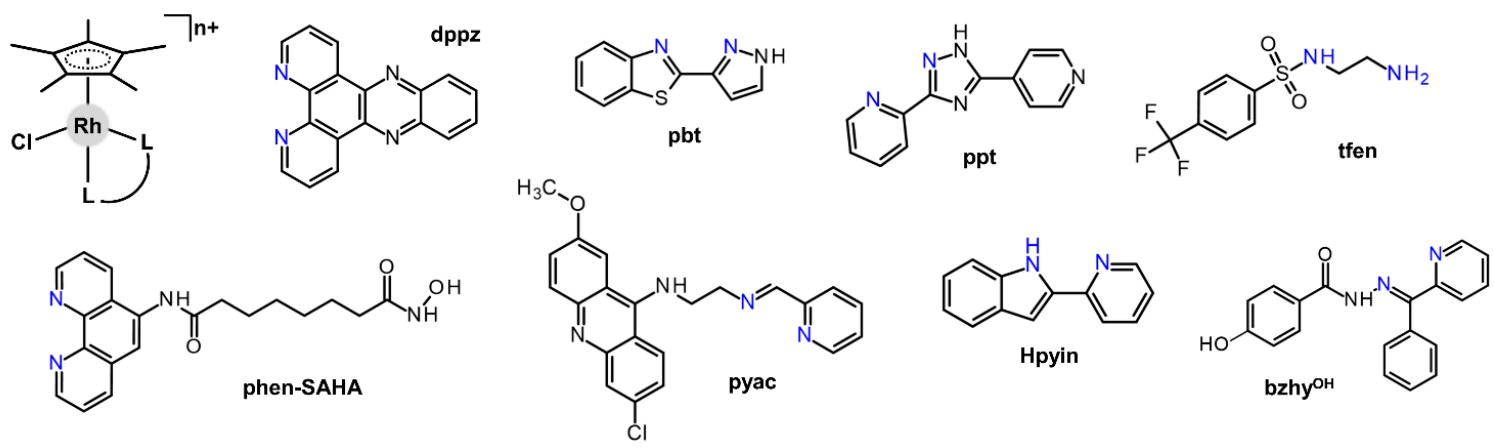

Figure 3. The general structural formula of the $\left[\mathrm{Rh}\left(\eta^{5}-\mathrm{Cp}^{*}\right)(\mathrm{L} \wedge \mathrm{L}) \mathrm{Cl}\right]^{\mathrm{n}+}$ complexes and structural formulas of selected bidentate $N, N$-donor $L^{\wedge} \mathrm{L}$ ligands, with donor nitrogen atoms given in blue.

Complexes $\left[\mathrm{Rh}\left(\eta^{5}-\mathrm{Cp}^{*}\right)\left(\mathrm{L}^{\wedge} \mathrm{L}\right) \mathrm{Cl}\right] \mathrm{PF}_{6}$, where $\mathrm{L}^{\wedge} \mathrm{L}=2-(1 \mathrm{H}$-pyrazol-3-yl)benzothiazole (pbt) or 3-(2-pyridyl)-5-(4-pyridyl)-1,2,4-triazole (ppt) (Figure 3), showed promising results obtained both in vitro and in vivo for the murine thymus gland lymphoma cells or Dalton's lymphoma ascites cells [64]. In particular, these complexes prolonged the survival times of the treated animals $(\mathrm{T} / \mathrm{C}=152 \%$ for the pbt complex at $15 \mathrm{mg} / \mathrm{kg}$ dose and $158 \%$ for the ppt complex at $30 \mathrm{mg} / \mathrm{kg}$ dose). No reference drug was used in this experiment, but only slightly higher activity was observed for the best-performing Ru complex $\left[R u\left(\eta^{6}\right.\right.$ bz)(ppt)Cl] $\mathrm{PF}_{6}(\mathrm{~T} / \mathrm{C}=211 \%$ at $30 \mathrm{mg} / \mathrm{kg}$ dose $)$.

A series of organorhodium complexes containing ethane-1,2-diamine (en), 2,2'-bipyri dine (bpy), phen or N-(2-aminoethyl)-4-(trifluoromethyl)benzenesulfonamide (tfen; Figure 3) showed high cytotoxicity towards the A2780 cells, which was even improved when administered with formate [38]. These Rh complexes were less cytotoxic, and their cytotoxicity did not increase with the $\mathrm{Cp}$ ring extension, as reported for their previously studied $\mathrm{Ir}$ analogues [65]. The studied Rh complexes also effectively catalysed the reduction of $\mathrm{NAD}^{+}$ to NADH.

A phen-based ligand (Figure 3) was also used for the preparation of the innovative $\mathrm{Rh}$ and $\mathrm{Ru}$ complexes bearing the histone deacetylase (HDAC) inhibitor suberoylanilide hydroxamic acid (SAHA), which represented the first half-sandwich complex having the inhibitory activity towards HDAC enzymes [39]. Cytotoxicity of both complexes towards the H460 non-small-cell lung carcinoma cells was, however, lower than for the free phenSAHA ligand and SAHA itself (Table 1).

Complex $\left[\mathrm{Rh}\left(\eta^{5}-\mathrm{Cp}^{*}\right)(\right.$ pyac $\left.) \mathrm{Cl}\right] \mathrm{BPh}_{4}\left(\mathrm{IC}_{50}=2.5 \mu \mathrm{M}\right)$ exceeded the potency of the $\mathrm{Ru}$, Os and Ir analogues $\left(\mathrm{IC}_{50}=3.5-9.2 \mu \mathrm{M}\right)$ and cisplatin $\left(\mathrm{IC}_{50}=6.6 \mu \mathrm{M}\right) ;$ pyac $=$ acridinecontaining 2-pyridylimine ligand (Figure 3) [66]. On the other hand, the selectivity of the Rh complex ( $\mathrm{SI}=1.2$ ) was lower than determined for the co-studied complexes $(\mathrm{SI}=3.2-5.5)$ and cisplatin $(\mathrm{SI}=6.4)$; FG0 normal skin fibroblast was used, $\mathrm{SI}=$ selectivity index.

Similarly, organorhodium complexes containing various benzhydrazone derivatives revealed superior potency over their $\mathrm{Ru}$ and Ir analogues (studied in the HCT116 ${ }^{+/+}$and HCT116 ${ }^{-/-}$cells) [40]. Additionally, complex $\left[\mathrm{Rh}\left(\eta^{5}-\mathrm{Cp}^{*}\right)\left(\mathrm{bzhy}{ }^{\mathrm{OH}}\right) \mathrm{Cl}\right] \mathrm{PF}_{6}$ containing the hydroxyl-substituted ligand (bzhy ${ }^{\mathrm{OH}}$; Figure 3, Table 1) showed greater selectivity towards the HCT116 cancer cells (SI = 51 for both the used HCT116 variants) over the non-cancerous ones (ARPE-19 retinal epithelium cell line) than the counterparts $(\mathrm{SI}=0.8-35)$ and cisplatin (SI $=1.0$ and 0.4 for the HCT116 ${ }^{+/+}$and $\mathrm{HCT}_{116^{-/-}}$cells, respectively).

Electroneutral complex $\left[\mathrm{Rh}\left(\eta^{5}-\mathrm{Cp}^{*}\right) \mathrm{Cl}(\mathrm{pyin})\right]$ can be also highlighted as more cytotoxic than $\mathrm{Ru}, \mathrm{Os}$ and $\mathrm{Ir}$ complexes containing the same chelating $\mathrm{N}, \mathrm{N}$-donor ligand $(\mathrm{Hpyin}=$ 2-(2-pyridinyl)-1H-indole; Figure 3, Table 1) [41].

Besides the described highly cytotoxic Rh arenyl complexes, numerous compounds of this structural type have been reported as inactive or markedly less effective than the used reference drugs against the used human cancer cells [32,33,67-83].

Complexes with $\mathrm{N}, \mathrm{O}$-ligands. Complex $\left[\mathrm{Rh}\left(\eta^{5}-\mathrm{Cp} \mathrm{p}^{*}\right) \mathrm{Cl}(\mathrm{hq})\right]$ containing quinolin-8olate (hq; Figure 4) was studied as a promising cytostatic agent against human melanoma 
cells in vitro, where it exceeded its Ir congener [84]. Moderate selectivity can be pointed out for this complex as well. This complex, as well as analogues with hq derivatives, was more recently studied in detail for its solution behaviour and cytotoxicity against the MES-SA human uterine sarcoma and its multidrug-resistant variant, where complex $\left[R h\left(\eta^{5}-\right.\right.$ $\left.\left.\mathrm{Cp}^{*}\right) \mathrm{Cl}(\mathrm{pphq})\right]$ even exceeded the potency of cisplatin; Hpphq = 7-(1-piperidinylmethyl)-8hydroxyquinoline (Figure 4) [85].<smiles>Oc1cccc2cccnc12</smiles><smiles>CC(C)=CCC1=C(O)C(=O)c2ccccc2C1=O</smiles>
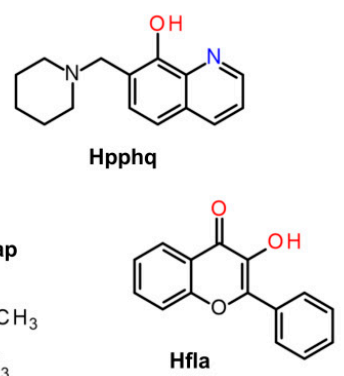

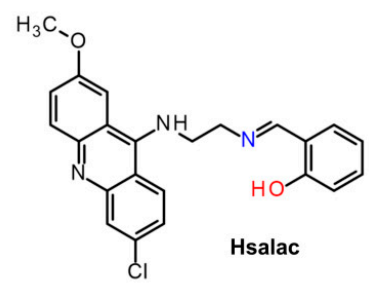

Figure 4. Structural formulas of selected bidentate $\mathrm{N}, \mathrm{O}$ - and $\mathrm{O}, \mathrm{O}$-donor $\mathrm{L}^{\wedge} \mathrm{L}$ ligands, with donor nitrogen and oxygen atoms given in blue and red, respectively.

Complex $\left[\mathrm{Rh}\left(\eta^{5}-\mathrm{Cp}^{*}\right) \mathrm{Cl}(\mathrm{salac})\right]\left(\mathrm{IC}_{50}=2.0 \mu \mathrm{M}\right.$; Figure 4$)$ was more cytotoxic in the HL60 cells than its ionic analogue $\left[\mathrm{Rh}\left(\eta^{5}-\mathrm{Cp} \mathrm{p}^{*}\right)(\mathrm{pyac}) \mathrm{Cl}\right] \mathrm{BPh}_{4}$ (see above) and than the co-studied Ru, Os and Ir complexes $\left(\mathrm{IC}_{50}=2.3-10.2 \mu \mathrm{M}\right)$ and cisplatin $\left(\mathrm{IC}_{50}=6.6 \mu \mathrm{M}\right)$ [66]. Nevertheless, the selectivity of this complex (SI $=3.3$ ) did not reach even the level of cisplatin $(\mathrm{SI}=6.4)$.

Other complexes did not reach the potency of the used reference drugs [53,86-89].

Complexes with $\mathrm{O}, \mathrm{O}$-ligands. Cytotoxicity of the first complex of this type, $\left[\mathrm{Rh}\left(\eta^{5}\right.\right.$ $\left.\left.\mathrm{Cp}^{*}\right) \mathrm{Cl}(\mathrm{lap})\right]$, was lower than for the free ligand lapachol (Hlap; Figure 4, Table 1), Ru and Os analogues and cisplatin [42]. This Rh complex hydrolysed in an aqueous solution and induced the formation of ROS, cell cycle arrest and apoptosis.

A pair of half-sandwich cyclopentadienyl rhodium(III) complexes with anticancer active curcumin (Hcur; Figure 4) and its bis-demethoxy derivative showed comparable activity in the cancer and normal cells (Table 1), suggesting their low selectivity [43]. Despite that, the following works reported this complex as a suitable drug-delivery system for curcumin, which is released from the complex under physiological conditions [90,91]. Another series of Rh complexes with curcumin or its derivatives showed complex $\left[R h\left(\eta^{5}\right.\right.$ $\left.\mathrm{Cp}^{*}\right) \mathrm{Cl}\left(\right.$ cur $\left.\left.^{1}\right)\right]$ as the best-performing one, with higher cytotoxicity than determined for its cur-based analogues, co-studied Ir complexes and cisplatin for the HepG2 (hepatocellular carcinoma) and HeLa cells, and with promising selectivity towards the cancer cell lines over the normal HEK-293 ones; Hcur $^{1}=(1 E, 6 E)$-1,7-bis(3,4-dimethoxyphenyl)-1,6-heptadiene3,5-dione (Figure 4) [92]. This complex interacted with DNA in a similar manner to cisplatin.

$\mathrm{Rh}, \mathrm{Ru}$ and Os complexes were studied for the impact of the metal centre on the biological activity of 3-hydroxyflavonol (Hfla; Figure 4, Table 1) and its derivatives used as their $\mathrm{O}, \mathrm{O}$-ligands [44]. The complexes featured high antiproliferative activity in the high $\mathrm{nM}$ to the low $\mu \mathrm{M}$ range and the $\mathrm{Rh}$ complexes were highlighted as promising candidates for future studies, thanks to their higher stability as compared with the Ru and Os counterparts.

For the series of complexes containing various $N$-substituted 1,3-dioxoindan-2-carboxa mides, only slight improvement of cytotoxicity of free ligands was obtained by their metalation [93]. Some other complexes reported in the literature to date have been less cytotoxic than the used reference drugs, or their activity was too low to be considered for future biological studies [87,94-97].

Complexes with $N, S$-ligands. In most cases, this structural type is represented by complexes containing thiourea derivatives or thiosemicarbazones. Three different pyrenyl-derived thiosemicarbazones (pytsc) were used for the preparation of half-sandwich $\mathrm{Rh}, \mathrm{Ru}$ and Ir complexes of the type $[\mathrm{M}(\mathrm{\eta}-\mathrm{ar})(\mathrm{pytsc}) \mathrm{Cl}] \mathrm{Cl}$ [45]. Among them, the Rh com- 
plexes were the most cytotoxic $\left(\mathrm{IC}_{50}=5.1-18.2 \mu \mathrm{M}\right.$ in the A549, DU-145, HeLa and MCF-7 cells) and revealed pharmacologically promising selectivity (SI $>10$ for $\left[\operatorname{Rh}\left(\eta^{5}-\right.\right.$ $\left.C \mathrm{p}^{*}\right)\left(\right.$ pytsc $\left.\left.^{1}\right) \mathrm{Cl}\right] \mathrm{Cl}$ ), which was markedly higher even as compared to doxorubicin $(\mathrm{SI}<1)$; pytsc $^{1}=$ pyrenecarboxaldehyde-3-thiosemicarbazone (Figure 5 , Table 1 ). The Rh complexes induced apoptosis and modified the cell cycle of the A549 cells. They also interacted with DNA (preferably with its surface).
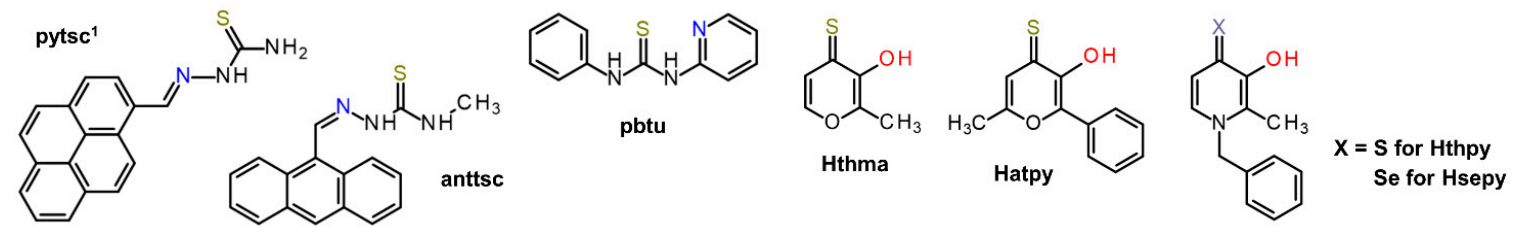

Figure 5. Structural formulas of selected bidentate $N, S-, O, S$ - and $O, S e$-donor L^L ligands, with donor atoms given in blue $(\mathrm{N})$, dark yellow $(\mathrm{S})$ or red $(\mathrm{O})$, and $\mathrm{X}$ stands for $\mathrm{S}$ or Se.

Similar Rh (and Ir) complexes containing anthracene-derived thiosemicarbazones (e.g., anttsc in Figure 5) were studied for their photo- and chemocytotoxic effects against human cancer cells [98]. The complexes showed a synergistic effect of the metal-based species (chemotherapeutic effect) and the anthracene substituent (photodynamic therapy). The observed cytotoxicity was higher when the cells were irradiated by visible light $\left(\lambda_{\text {irr }}>400 \mathrm{~nm}, 30 \mathrm{~min}\right)$, with the determined PI values of 1.7-4.1 for the Rh complexes (2.5-7.4 for Ir ones); PI = phototoxicity index.

In total, six different $N$-phenyl/benzoyl- $N$-pyridyl/2-picoline/pyrimidyl thiourea ligands (e.g., pbtu in Figure 5) were included in a series of Rh, Ru and Ir complexes, which, generally said, did not show higher cytotoxicity than the used reference-drug cisplatin (Table 1) [46,61]. Similarly, Rh complexes with two different heterocyclic thione ligands (e.g., benzimidazole-2-thione-based ligand, bzit) were inactive in the used cancer cell lines (Table 1) [47]. Despite that, these complexes have to be highlighted, because the ligands used unusually form 7-membered chelating rings with the metal centres used.

Complexes with $\mathrm{O}, \mathrm{S}$ - and $\mathrm{O}, \mathrm{Se}$-ligands. $\mathrm{Rh}$ and $\mathrm{Ru}$ complexes involving 2-aryl4-thiopyrones (e.g., Hatpy in Figure 5 and Table 1) were more stable under aqueous conditions as compared with similar complexes derived from $\mathrm{O}, \mathrm{O}$-donor flavonol-based ligands [48]. Organorhodium complexes were more cytotoxic $\left(\mathrm{IC}_{50}=0.5-3.8 \mu \mathrm{M}\right)$ than their $\mathrm{Ru}(\mathrm{II})$ counterparts $\left(\mathrm{IC}_{50}=3.4-16.0 \mu \mathrm{M}\right)$.

Similarly, thiomaltol (Hthma; Figure 5) compounds were more stable in solution than complexes containing pyrone derivatives [49]. Cytotoxicity of the thiomaltol-derived arene/arenyl compounds followed the order of $\mathrm{Ir}>\mathrm{Rh}>\mathrm{Os}>\mathrm{Ru}$. Regarding complex $\left[\mathrm{Rh}\left(\eta^{5}-\mathrm{Cp}^{*}\right) \mathrm{Cl}(\right.$ thma $\left.)\right]$, it exceeded NKP-1339 (i.e., IT-139) in all the A549, CH1/PA-1 and SW480 cell lines, and cisplatin in the SW480 cells (Table 1). Complexes effectively inhibited topoisomerase (topo) II $\alpha$ and circumvented the cell cycle. Complex [Rh $\left(\eta^{5}-\mathrm{Cp}{ }^{*}\right) \mathrm{Cl}($ thma) $]$ was further studied as a building-block for a degradable poly(organo)phosphazene macromolecule in order to improve its pharmacodynamics and cytotoxicity [99]. The studied polynuclear adduct was highly stable in a neutral aqueous environment; however, the released complex was observed only in acidic solution, which implied the selective release in lysosomes. Complex $\left[\mathrm{Rh}\left(\eta^{5}-\mathrm{Cp}^{*}\right) \mathrm{Cl}(\right.$ thma $\left.)\right]$ exceeded the in vitro efficacy of its multinuclear congener, and both these agents were more cytotoxic than the $\mathrm{Ru}$ analogues. In addition, the anticancer activity and organ distribution of the poly(organo)phosphazene $\mathrm{Rh}$ conjugate were studied in vivo in mice bearing the CT- 26 colon carcinoma. The highest metal contents were found in the liver and kidneys, while only low concentrations were observed in other tissues.

Structurally close thiopyridone-based complexes showed excellent water solubility and remarkable antiproliferative activity, which was in some cases even higher than for the above discussed thiomaltol complex [50]. This was connected with the observed formation of dicationic dimeric species under physiological conditions. The lowest $\mathrm{IC}_{50}$ values were 
achieved for $\left[\mathrm{Rh}\left(\eta^{5}-\mathrm{Cp} \mathrm{p}^{*}\right) \mathrm{Cl}(\right.$ thpy $\left.)\right]\left(\mathrm{IC}_{50}=0.3-0.7 \mu \mathrm{M}\right.$; Table 1), which correlated with its extensive intracellular accumulation in the cancer cells; Hthpy = 1-benzyl-3-hydroxy-2methylpyridin-4(1H)-one (Figure 5).

Bidentate selenopyridones were used for the preparation of organorhodium compounds and the performed exchange of $O, S$-donor thiopyridones for these $O, S$-ligands (e.g., Hsepy in Figure 5) resulted in cytotoxicity decrease, as reported for complex $\left[\mathrm{Rh}\left(\mathrm{\eta}^{5}\right.\right.$ $\left.\mathrm{Cp}^{*}\right) \mathrm{Cl}\left(\right.$ sepy $\left.^{1}\right)$ ] (Table 1); Hsepy ${ }^{1}=1$-methyl-3-hydroxy-2-methylpyridin-4(1H)-selenone [51].

Complexes with $C, N$-ligands. The steroidal conjugate $\left[\mathrm{Rh}\left(\eta^{5}-\mathrm{Cp}^{*}\right) \mathrm{Cl}\left(\mathrm{ppy}^{1}\right)\right]$ bearing the ppy-based lipophilic levonorgestrel moiety 17- $\alpha$-[2-phenylpyridyl-4-ethynyl]-19nortestosterone $\left(\mathrm{Hppy}^{1}\right.$; Figure 6, Table 1) was more active than cisplatin in the T47D breast and A2780R cisplatin-resistant ovarian cancer cell lines, while its potency was lower than for cisplatin in the cisplatin-sensitive A2780 cells; Hppy = 2-phenylpyridine [52]. Further, this innovative organorhodium complex was comparably cytotoxic with its Ir complex and slightly more effective than the complex prepared for comparative purposes with unsubstituted ppy. Both the Rh and Ir complexes interacted with DNA and inhibited the cathepsin B enzyme.
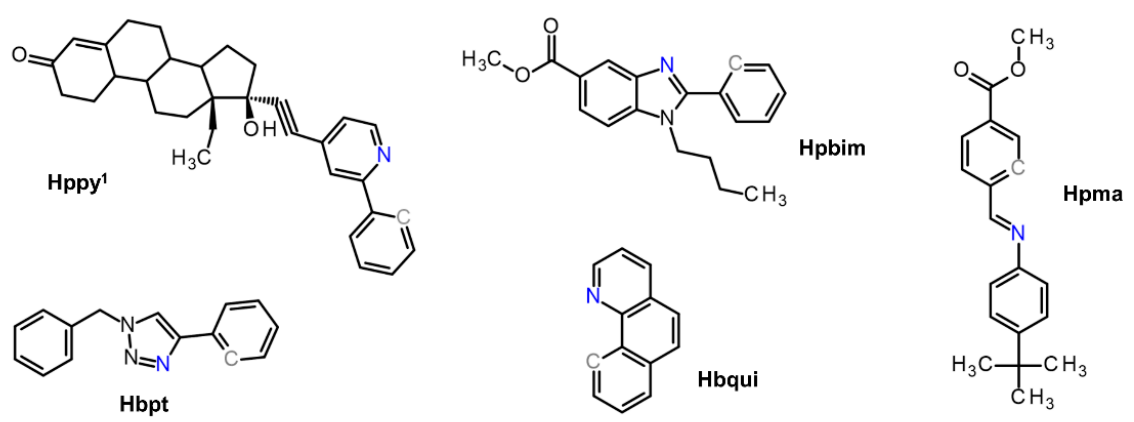

Figure 6. Structural formulas of selected bidentate $C, N$-donor $L^{\wedge} L$ ligands, with donor atoms given in blue $(\mathrm{N})$ or grey $(\mathrm{C})$.

An Rh complex with the $C, N$-coordinated 1-benzyl-4-phenyl-1H-1,2,3-triazole ( $\mathrm{Hbpt}$; Figure 6, Table 1) showed comparable cytotoxicity to that of auranofin in the A549 lung cancer cell line, but its selectivity towards the HEK-293 cells was low [53].

$\mathrm{Rh}, \mathrm{Ru}$ and Ir complexes with 2-phenylbenzimidazol-based ligands (Hpbim; Figure 6) were more active towards the T47D, HT-29 and A2780R cell lines than cisplatin (Table 1) [54]. Although their activity was mutually comparable in the T47D cells, Rh complex was markedly less accumulated in these cells than both the Ru and Ir analogues. Those complexes induced apoptosis of the HT-29 cells and modified their cell cycle (S-phase arrest).

Rh complexes with the Schiff base $N-[(E)$-phenylmethylidene]aniline-based ligands (e.g., Hpma in Figure 6) exhibited significant and higher than cisplatin cytotoxicity against the A549 cell line (Table 1), which correlated with the ROS populations induced in the treated cells [55]. Complexes also interacted with DNA and induced apoptosis.

Complexes $\left[\mathrm{Rh}\left(\eta^{5}-\mathrm{Cp}^{\mathrm{x}}\right)(\mathrm{bqui}) \mathrm{Cl}\right]$, where $\mathrm{Cp}^{\mathrm{x}}=\mathrm{Cp}^{*}, \mathrm{Cp}^{\mathrm{ph}}$ or $\mathrm{Cp} \mathrm{p}^{\mathrm{bph}}$, and Hbqui $=$ benzo[ $h]$ quinoline (Figure 6 ), showed lower antiproliferative activity than their ionic pyridine counterparts (see below) and than cisplatin (Table 1); $\mathrm{HCp}^{\mathrm{ph}}=(2,3,4,5$-tetramethylcyclo penta-2,4-dien-1-yl)benzene and $\mathrm{HC} \mathrm{p}^{\mathrm{bph}}=4$-(2,3,4,5-tetramethylcyclopenta-2,4-dien-1yl)biphenyl [56].

\subsubsection{Other Types of Monodentate Ligands}

This structural type is in most cases represented by $\left[R h\left(\eta^{5}-\mathrm{Cp}^{\mathrm{x}}\right)\left(\mathrm{L}^{\wedge} \mathrm{L}\right) \mathrm{X}\right]^{\mathrm{n}+}$ complexes, where $\mathrm{X}$ is a monodentate ligand coordinated through the $\mathrm{P}, \mathrm{N}, \mathrm{O}$ or $\mathrm{S}$ donor atom $(n=0$ or 1 depending on the charge of $\mathrm{L}^{\wedge} \mathrm{L}$ and $\left.\mathrm{X}\right)$.

The polypyridyl complexes $\left[\mathrm{Rh}\left(\eta^{5}-\mathrm{Cp}^{*}\right)(\mathrm{pp}) \mathrm{X}\right]\left(\mathrm{CF}_{3} \mathrm{SO}_{3}\right)_{\mathrm{n}}$ contain the $S$-donor ligand $(\mathrm{X})$ tetramethyl thiourea $(n=2)$, benzenethiolate (bzth; $n=1)$ or naphthalene-2-thiolate (npth; $n=1$ ) instead of the above discussed chlorido ligand of the co-studied chlorido 
complexes (see above) [36]. Complexes $\left[\mathrm{Rh}\left(\eta^{5}-\mathrm{Cp} \mathrm{p}^{*}\right)(\mathrm{dppz})(\mathrm{bzth})\right] \mathrm{CF}_{3} \mathrm{SO}_{3}$ (Figure 7) and $\left[\mathrm{Rh}\left(\eta^{5}-\mathrm{Cp}^{*}\right)(\mathrm{dppz})(\mathrm{npth})\right] \mathrm{CF}_{3} \mathrm{SO}_{3}$ were more cytotoxic for the MCF-7 and HT-29 cancer cells (Table 2) than their chlorido analogues (Table 1).
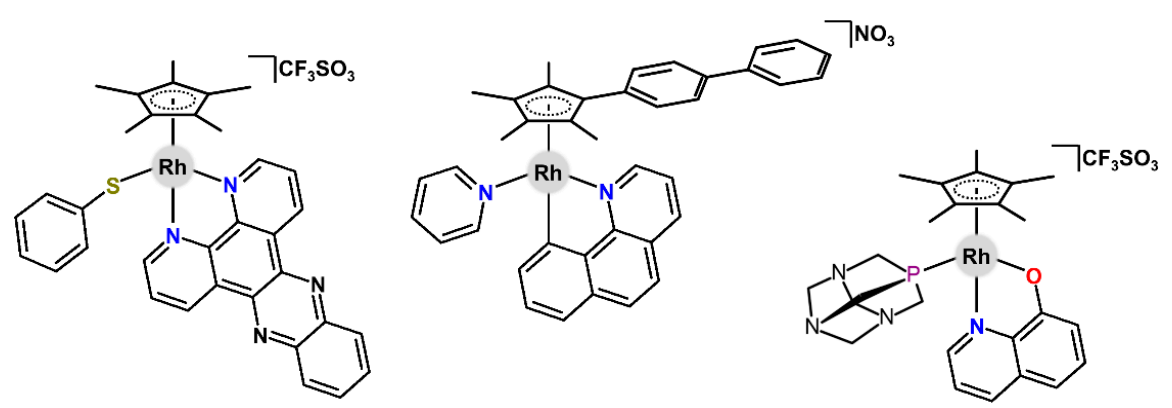

Figure 7. Structural formulas of complexes $\left[\mathrm{Rh}\left(\eta^{5}-\mathrm{Cp}^{*}\right)(\mathrm{dppz})(\mathrm{bzth})\right] \mathrm{CF}_{3} \mathrm{SO}_{3}$ (left), $\left[\mathrm{Rh}\left(\eta^{5}-\mathrm{Cp}^{\mathrm{bph}}\right)\right.$ (py)(bqui)] $\mathrm{NO}_{3}$ (middle) and $\left[\mathrm{Rh}\left(\eta^{5}-\mathrm{Cp}^{*}\right)(\right.$ pta) $(\mathrm{hq})] \mathrm{CF}_{3} \mathrm{SO}_{3}$ (right), with donor atoms given in blue $(\mathrm{N})$, dark yellow $(\mathrm{S})$, magenta $(\mathrm{P})$ or red $(\mathrm{O})$.

The structurally untypical electroneutral complex $\left[R h\left(\eta^{5}-C p^{*}\right)(\right.$ pyth- $N, S)($ pyth-S)], which contains two differently coordinated pyrimidine-2-thiolates (pyth) in its structure showed lower cytotoxicity than cisplatin (Table 2) [100]. This complex interacted with DNA.

Complexes $\left[\mathrm{Rh}\left(\eta^{5}-\mathrm{Cp}^{\mathrm{x}}\right)(\mathrm{py})(\mathrm{bqui})\right] \mathrm{NO}_{3}$ were more potent in the A549 cells than the chlorido analogues; $\mathrm{Cp}^{\mathrm{x}}=\mathrm{Cp}^{*}, \mathrm{Cp}^{\mathrm{ph}}$ or $\mathrm{Cp}^{\mathrm{bph}}$ [56]. The best-performing complex $\left[\mathrm{Rh}\left(\eta^{5}\right.\right.$ $\left.\mathrm{Cp}^{\mathrm{bph}}\right)(\mathrm{py})(\mathrm{bqui}) \mathrm{NO}_{3}$ (Figure 7 , Table 2) was even more active than cisplatin. Unexpectedly, the cellular accumulation of the py complex in the A549 cells was several times lower than determined for its less active chlorido congener. Other differences between the studied py-based and chlorido complexes are discussed below.

Similarly, a series of complexes $\left[R h\left(\eta^{5}-\mathrm{Cp}^{*}\right)\left(\mathrm{py}^{\mathrm{n}}\right)\left(\mathrm{sai}^{1}\right)\right] \mathrm{BPh}_{4}$ was based on monodentate $\mathrm{N}$-donor pyridines $\left(\mathrm{py}^{\mathrm{n}}=\right.$ pyridine, 4-methylpyridine, 4-phenylpyridine and 4-ferrocenylpyridine), this time in combination with the bidentate $\mathrm{N}, \mathrm{O}$-donor ligand 4hydroxy-3-[(E)-(propylimino)methyl]benzene-1-sulfonate (Hsai ${ }^{1}$ ) [101]. These Rh complexes showed lower cytotoxic activity than cisplatin against the WHCO-1 (esophageal carcinoma) cell line, but they were more potent than their Ir counterparts.

Using 1-methylimidazole as a leaving moiety in place of the chlorido ligand increased the stability and solubility of the thiomaltol-based organorhodium compounds, which may allow their accumulation and control of their activation [49]. The cytotoxicity of these compounds was promising, particularly for the best performing $R h$ complex $\left[R h\left(\eta^{5}-\right.\right.$ $\left(\mathrm{p}^{*}\right)(\mathrm{meim})(\mathrm{thma}) \mathrm{PF}_{6}$ reaching even sub-micromolar activity (Table 2).

Complexes $\left[\mathrm{Rh}\left(\eta^{5}-\mathrm{Cp}^{*}\right)(\mathrm{pta})(\mathrm{hq})\right] \mathrm{CF}_{3} \mathrm{SO}_{3}$ and $\left[\mathrm{Rh}\left(\eta^{5}-\mathrm{Cp} \mathrm{p}^{*}\right)(\mathrm{pta})\left(\mathrm{hq} \mathrm{q}^{1}\right)\right] \mathrm{CF}_{3} \mathrm{SO}_{3}$ contain, analogically with RAPTA-C, pta as a monodentate $P$-donor ligand (Figure 7), and achieved higher or comparable activity to cisplatin and significantly higher activity than RAPTA-C in the used HCT-116 (colorectal), NCI-H460 (lung), SiHa (cervical) and SW480 (colon) cancer cell lines $\left(\mathrm{IC}_{50}=0.9-11 \mu \mathrm{M}\right.$; Table 2); Hhq = 8-hydroxyquinoline, $\mathrm{Hhq}^{1}=5$-chloro-7-iodo-8hydroxyquinoline [102]. Surprisingly, both the $\mathrm{Rh}(\mathrm{III})$ complexes exhibited significantly higher cytotoxicity than analogous $\mathrm{Ru}(\mathrm{II}), \mathrm{Os}$ (II) and $\mathrm{Ir}(\mathrm{III})$ complexes, meaning that rhodium complexes appeared to be the most suitable candidates for further study from the whole prepared series. Both Rh complexes were stable in water, DMSO as well as in the solvent mixture mimicking the cell environment.

Organorhodium curcumin-based complexes were studied with pta [43]. Similarly to the above discussed chlorido complexes, the pta counterparts, such as $\left[\mathrm{Rh}\left(\eta^{5}-\mathrm{Cp} \mathrm{p}^{*}\right)(\mathrm{pta})(\mathrm{cur})\right]$ $\mathrm{CF}_{3} \mathrm{SO}_{3}$ (Table 2), were also only moderately cytotoxic with comparable activity in the cancer and non-cancerous cell lines. 
Table 2. In vitro cytotoxicity of $\left[\mathrm{Rh}\left(\eta^{5}-\mathrm{Cp}^{\mathrm{x}}\right)(\mathrm{L} \wedge \mathrm{L}) \mathrm{X}\right]^{\mathrm{n}+}$ complexes, different types of organorhodium arenyl complexes and multinuclear complexes (both homo- and heteronuclear) against the selected types of cancer, given together with the results obtained for the non-cancerous (normal) cells. The results are summarised together with the co-studied reference drugs (in parentheses; cisplatin unless stated otherwise), where available. $\mathrm{Cp}^{\mathrm{x}}=$ cyclopentadienyl ligand, $\mathrm{L}^{\wedge} \mathrm{L}=$ a bidentate ligand, $\mathrm{X}=$ a monodentate ligand coordinated through the $\mathrm{P}, \mathrm{N}, \mathrm{O}$ or $\mathrm{S}$ donor atom.

\begin{tabular}{|c|c|c|c|c|c|c|}
\hline Complex & Ovarian $^{a}$ & Lung $^{c}$ & Breast $^{\mathrm{f}}$ & Colon $\mathrm{g}$ & Normal $^{j}$ & Ref. \\
\hline$\left[\mathrm{Rh}\left(\eta^{5}-\mathrm{Cp}^{*}\right)(\mathrm{dppz})(\mathrm{npth}) \mathrm{CF}_{3} \mathrm{SO}_{3}\right.$ & - & - & $0.6(2.0)$ & $3.3(7.0)$ & - & [36] \\
\hline$\left[R h\left(\eta^{5}-C p^{*}\right)(p y t h-N, S)(\right.$ pyth-S)] & - & - & - & $20.3(0.3)$ & $39.5(6.4)^{k}$ & {$[100]$} \\
\hline$\left[\mathrm{Rh}\left(\eta^{5}-\mathrm{Cp}^{\mathrm{bph}}\right)(\mathrm{py})(\mathrm{bqui}) \mathrm{NO}_{3}\right.$ & $0.9(1.0)$ & $0.7(3.8)$ & - & - & - & [56] \\
\hline$\left[\mathrm{Rh}\left(\eta^{5}-\mathrm{Cp}^{*}\right)(\right.$ meim $)($ thma $\left.)\right] \mathrm{PF}_{6}$ & $0.9^{\mathrm{b}}(0.2)$ & $2.6(1.3)$ & - & $0.5(3.5)^{\mathrm{h}}$ & - & [49] \\
\hline$\left[\mathrm{Rh}\left(\eta^{5}-\mathrm{Cp}^{*}\right)(\mathrm{pta})(\mathrm{hq}) \mathrm{CF}_{3} \mathrm{SO}_{3}\right.$ & - & $2.0(0.8)^{d}$ & - & $0.9(2.5)^{\mathrm{i}}$ & - & {$[102]$} \\
\hline$\left[\mathrm{Rh}\left(\eta^{5}-\mathrm{Cp}^{*}\right)(\mathrm{pta})(\mathrm{cur})\right] \mathrm{CF}_{3} \mathrm{SO}_{3}$ & 12.5 & - & - & - & 17.2 & [43] \\
\hline$\left[\mathrm{Rh}\left(\eta^{5}-\mathrm{Cp}^{*}\right)(\mathrm{dpa}) \mathrm{I}\right] \mathrm{PF}_{6}$ & $70.1(5.9)$ & - & - & - & - & [81] \\
\hline$\left[\mathrm{Rh}\left(\eta^{5}-\mathrm{Cp}^{*}\right)(\mathrm{met})\right] \mathrm{Cl}$ & $>50.0(3.4)$ & - & - & - & - & [103] \\
\hline$\left[\mathrm{Rh}\left(\eta^{5}-\mathrm{Cp}^{*}\right)\left(\right.\right.$ patt $\left.\left.^{1}\right)\right] \mathrm{Cl}$ & $21.0(2.3)$ & - & - & - & $>200(8.4)$ & {$[104]$} \\
\hline$\left[R h\left(\eta^{5}-C p^{*}\right)\left(\eta^{4}-b q^{n}\right)\right]$ & $>400(3.0)$ & - & - & - & - & [105] \\
\hline$\left[\mathrm{Rh}\left(\eta^{5}-\mathrm{Cp}^{\mathrm{as}}\right)(\mathrm{CO})_{2}\right]$ & - & - & $10.2(2.0)$ & $9.2(2.4)$ & - & [106] \\
\hline$\left[\mathrm{Rh}_{2}\left(\mu-\mathrm{mal}^{1}\right)\left(\eta^{5}-\mathrm{Cp}^{*}\right)_{2} \mathrm{Cl}_{2}\right]$ & - & $0.1(0.8)^{d}$ & - & $0.2(2.5)^{\mathrm{i}}$ & - & {$[107]$} \\
\hline$\left[\mathrm{Rh}_{2}(\mu-\mathrm{dhbq})\left(\eta^{5}-\mathrm{Cp}^{*}\right)_{2} \mathrm{Cl}_{2}\right]$ & - & $0.7(1.0)^{\mathrm{e}}$ & $0.8(0.9)^{\mathrm{e}}$ & - & $1.1^{1}(1.2)^{\mathrm{e}}$ & [108] \\
\hline$\left[\mathrm{Rh}_{2}\left(\mu-\mathrm{SR}^{1}\right)_{2}\left(\eta^{5}-\mathrm{Cp}^{*}\right)_{2} \mathrm{Cl}_{2}\right]$ & $1.1(1.6)$ & - & - & - & $1.0(8.6)$ & [109] \\
\hline$\left[\mathrm{Rh}_{2}\left(\mu-\mathrm{SR}^{1}\right)_{3}\left(\eta^{5}-\mathrm{Cp}^{*}\right)_{2}\right] \mathrm{Cl}$ & $0.1(1.6)$ & - & - & - & $0.1(8.6)$ & [109] \\
\hline $\begin{array}{c}{\left[\mathrm{Rh}_{4}(\mu-\mathrm{dhbq})_{2}(\mu-\mathrm{pyz})_{2}\left(\eta^{5}-\right.\right.} \\
\left.\left.\mathrm{Cp}^{*}\right)_{4}\right]\left(\mathrm{CF}_{3} \mathrm{SO}_{3}\right)_{4}\end{array}$ & - & $0.5(0.9)^{\mathrm{e}}$ & - & - & 62.0 & [110] \\
\hline $\begin{array}{c}{\left[\mathrm{Rh}_{6}(\mu-\mathrm{dhbq})_{3}(\mu-\mathrm{tpt})_{2}\left(\eta^{5}-\right.\right.} \\
\left.\left.\mathrm{Cp}^{*}\right)_{6}\right]\left(\mathrm{CF}_{3} \mathrm{SO}_{3}\right)_{6}\end{array}$ & - & $0.5(1.0)^{\mathrm{e}}$ & $0.5(0.9)^{\mathrm{e}}$ & - & $1.0^{1}(1.2)^{\mathrm{e}}$ & [108] \\
\hline $\begin{array}{c}{\left[\mathrm{Rh}_{8}(\mu-\mathrm{dhbq})_{4}(\mu-\mathrm{tpp})_{2}\left(\eta^{5}-\right.\right.} \\
\left.\left.\mathrm{Cp}^{*}\right)_{8}\right]\left(\mathrm{CF}_{3} \mathrm{SO}_{3}\right)_{8}\end{array}$ & - & 70.0 & 72.0 & - & $98.0^{\mathrm{m}}$ & [111] \\
\hline$\left[\mathrm{Rh}\left(\eta^{5}-\mathrm{Cp}^{*}\right)\left(\mathrm{py}^{\mathrm{Fc}}\right)(\right.$ saea $\left.)\right] \mathrm{PF}_{6}$ & $59.0(1.5)$ & - & - & - & $65.5(10.0)$ & [112] \\
\hline $\begin{array}{c}{\left[\mathrm{Rh}_{8}\left(\mu-\mathrm{saea}^{1}\right)\left(\eta^{5}-\right.\right.} \\
\left.\left.\mathrm{Cp}^{*}\right)_{8}\left(\mathrm{py}^{\mathrm{Fc}}\right)_{8}\right]\left(\mathrm{PF}_{6}\right)_{8}\end{array}$ & $10.7(1.5)$ & - & - & - & $9.4(10.0)$ & [112] \\
\hline $\begin{array}{c}{\left[\mathrm{Cl}_{2}\left(\eta^{5}-\mathrm{Cp}^{*}\right) \mathrm{Rh}(\mu-\right.} \\
\left.\left.\text { bpy }^{\mathrm{PPh} 3}\right) \operatorname{Ru}(\mathrm{bpy})_{2}\right]\left(\mathrm{PF}_{6}\right)_{2}\end{array}$ & $>50(2.5)$ & $>50(8.0)$ & - & - & - & [113] \\
\hline
\end{tabular}

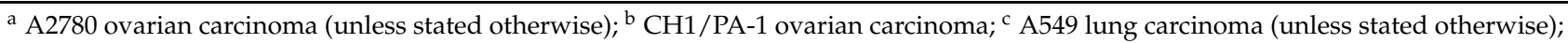

${ }^{d}$ NCI-H460 lung carcinoma; ${ }^{e}$ doxorubicin was used as the reference drug; ${ }^{\mathrm{f}}$ MCF-7 breast adenocarcinoma; ${ }^{\mathrm{g}} \mathrm{HT}-29$ colorectal adenocarcinoma (unless stated otherwise); ${ }^{\mathrm{h}}$ SW480 colorectal adenocarcinoma; ${ }^{i}$ HCT-116 colorectal carcinoma; ${ }^{\mathrm{j}}$ HEK-293 embryonic kidney epithelial cells; ${ }^{\mathrm{k}}$ ARPE-19 retinal pigmented epithelial cells; ${ }^{1}$ CRL-2115 skin fibroblasts; ${ }^{\mathrm{m}}$ NIH 3 T3 mouse embryonic fibroblasts.

The iodido complex $\left[\mathrm{Rh}\left(\eta^{5}-\mathrm{Cp}^{*}\right)(\mathrm{dpa}) \mathrm{I}\right] \mathrm{PF}_{6}$ exceeded the cytotoxicity of its inactive bromido and chlorido analogues (Table 2); dpa =2,2'-dipyridylamine [81]. In general, for this work, the reported Rh complexes were less cytotoxic than the co-studied Ir complexes.

\subsection{Complexes with a Tridentate Ligand}

The structural type with all the three legs of the piano-stool occupied by one tridentate ligand is less common than the above discussed complexes with three monodentate ligands (Section 2.1) or with a combination of bidentate and monodentate ligands (Section 2.2). To the best of our knowledge, this type of half-sandwich organorhodium complex has been reported only in two works. Complex $\left[\mathrm{Rh}\left(\eta^{5}-\mathrm{Cp} *\right)(\right.$ met $\left.)\right] \mathrm{Cl}$, containing $\mathrm{O}, \mathrm{N}, \mathrm{S}$-coordinated 


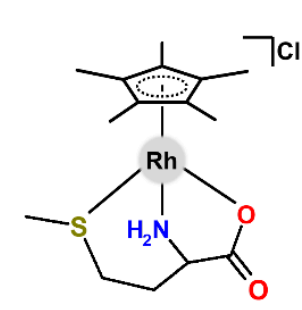

mono-deprotonated DL-methionine (met; Figure 8) was not cytotoxic in the A2780 and A2780R cells (Table 2) [103].
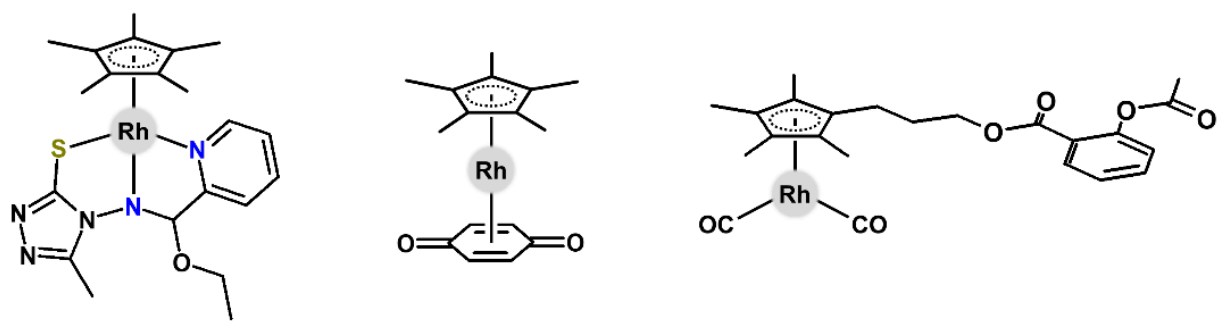

Figure 8. Structural formulas of complexes $\left[\mathrm{Rh}\left(\eta^{5}-\mathrm{C} \mathrm{p}^{*}\right)(\mathrm{met})\right] \mathrm{Cl}(\mathrm{left}),\left[\mathrm{Rh}\left(\eta^{5}-\mathrm{C} \mathrm{p}^{*}\right)\left(\mathrm{patt}{ }^{1}\right)\right] \mathrm{Cl}(\mathrm{middle}$ left $),\left[\mathrm{Rh}\left(\eta^{5}-\mathrm{C} \mathrm{p}^{*}\right)\left(\eta^{4}-\right.\right.$ $\left.\left.\mathrm{bq}^{\text {para }}\right)\right]$ (middle right) and $\left[\mathrm{Rh}\left(\eta^{5}-\mathrm{Cp}^{\text {as }}\right)(\mathrm{CO})_{2}\right]$ (right), with donor atoms given in blue $(\mathrm{N})$, dark yellow $(\mathrm{S})$ or red $(\mathrm{O})$.

Another work reported a series of $\left[\mathrm{Rh}\left(\eta^{5}-\mathrm{Cp}^{*}\right)\left(\right.\right.$ patt $\left.\left.^{\mathrm{n}}\right)\right] \mathrm{Cl}$ complexes containing the deprotonated Schiff base 5-methyl-4-\{(pyridin-2-ylmethylene)amino\}-4H-1,2,4-triazole-3-thiol as an $N, N, S$-donor ligand derived by alcohols (methanol, ethanol, isopropanol) alkoxylating the imine carbon atom ( patt $^{\mathrm{n}}$ ) [104]. Only the ethoxy derivative (patt ${ }^{1}$; Figure 8, Table 2) showed some antiproliferative activity, with the $\mathrm{IC}_{50}$ being $21 \mu \mathrm{M}$ in the $\mathrm{A} 2780$ cells, which was still markedly lower potency than for the reference drug cisplatin $\left(\mathrm{IC}_{50}=2.3 \mu \mathrm{M}\right)$ but superior over its $\mathrm{Ru}$ analogue and RAPTA-C ( $\mathrm{IC}_{50}>200 \mu \mathrm{M}$ for both complexes).

\subsection{Other Types of Mononuclear Complexes}

Structurally interesting complexes $\left[R h\left(\eta^{5}-C p^{*}\right)\left(\eta^{4}-b q^{n}\right)\right]$ can be referred to as sandwich complexes, since they contain two $\eta$-coordinated rings at the central Rh atom (Figure 8); $\mathrm{bq}^{\mathrm{n}}=$ benzoquinone (ortho or para (bq $\left.{ }^{\text {para }}\right)$ ) [105]. Complexes were inactive against the A2780 cell line (Table $2 ; \mathrm{IC}_{50}=3.0 \mu \mathrm{M}$ for cisplatin and $93.0 \mu \mathrm{M}$ for $\left.\left[\operatorname{Ir}\left(\eta^{5}-\mathrm{C} \mathrm{p}^{*}\right)\left(\eta^{4}-\mathrm{bq}{ }^{\text {para }}\right)\right]\right)$.

Another structurally unusual complex, $\left[\mathrm{Rh}\left(\eta^{5}-\mathrm{Cp}^{\mathrm{as}}\right)(\mathrm{CO})_{2}\right]$, belongs to the family of metalcarbonyl complexes and contains (cyclopenta-1,3-dienyl)propyl-2-acetoxybenzoate $\left(\mathrm{Cp}^{\mathrm{as}}\right)$ as a $\eta$-coordinated cyclopentadiene-based arenyl ligand bearing the acetylsalicylate moiety (Figure 8) [106]. This complex achieved lower activity $\left(\mathrm{IC}_{50}=9.2-26.6 \mu \mathrm{M}\right)$ than cisplatin $\left(\mathrm{IC}_{50}=2.0-3.3 \mu \mathrm{M}\right)$ in the MCF-7, MDA-MB-231 and HT-29 cell lines (Table 2) and inhibited cyclooxygenase-1.

\section{Multinuclear Complexes}

This topic has very recently been reviewed elsewhere [23], which is why we decided to demonstrate this structural type only through the best-performing representatives, and update this field with the most recently reported multinuclear organorhodium compounds.

\subsection{Chlorido Complexes}

$\mathrm{Rh}$ arenyl chlorido complexes have been derived from various ligands to get compounds of various nuclearity, ranging from dinuclear complexes to dendrimers bearing up to 32 metal centres.

A series of dinuclear $\left[\mathrm{Rh}_{2}\left(\mu-\mathrm{mal}^{\mathrm{n}}\right)\left(\eta^{5}-\mathrm{Cp}^{*}\right)_{2} \mathrm{Cl}_{2}\right]$ complexes contain bis(3-hydroxy-2methyl-4-pyridinon-1-yl)alkanes $\left(\mathrm{Hmal}^{\mathrm{n}}\right)$ as the bridging ligands [107]. Complex $\left[\mathrm{Rh}_{2}(\mu-\right.$ $\left.\left.\mathrm{mal}^{1}\right)\left(\eta^{5}-\mathrm{Cp}^{*}\right)_{2} \mathrm{Cl}_{2}\right]$ (Figure 9, Table 2$)$ was markedly more cytotoxic $\left(\mathrm{IC}_{50}=0.1-0.5 \mu \mathrm{M}\right)$ than analogues with shorter aliphatic linkers and exceeded the cytotoxicity of analogical $\mathrm{Ru}$ and $\mathrm{Ir}$ complexes, and of the reference drugs cisplatin $\left(\mathrm{IC}_{50}=0.8-8.1 \mu \mathrm{M}\right)$ and IT-139 $\left(\mathrm{IC}_{50}=84-102 \mu \mathrm{M}\right)$; Hmal $^{1}=$ bis(3-hydroxy-2-methyl-4-pyridinon-1-yl)dodecane. Complex $\left[\mathrm{Rh}_{2}\left(\mu-\mathrm{mal}^{1}\right)\left(\eta^{5}-\mathrm{Cp}^{*}\right)_{2} \mathrm{Cl}_{2}\right]$ induced ROS formation and DNA damage. Importantly, this complex showed, in contrast to cisplatin, low toxicity in the in vitro haemolytic studies using mouse red blood cells and in vivo in transgenic zebrafish embryos. A similar highly cytotoxic dinuclear complex, $\left[\mathrm{Rh}_{2}(\mu-\mathrm{dhbq})\left(\eta^{5}-\mathrm{Cp}^{*}\right)_{2} \mathrm{Cl}_{2}\right]$, was used as the precursor of Rh-based metallacages (Table 2); $\mathrm{H}_{2} \mathrm{dhbq}=$ 2,5-dihydroxy-3-undecylcyclohexa-2,5-diene1,4-dione [108,110]. 

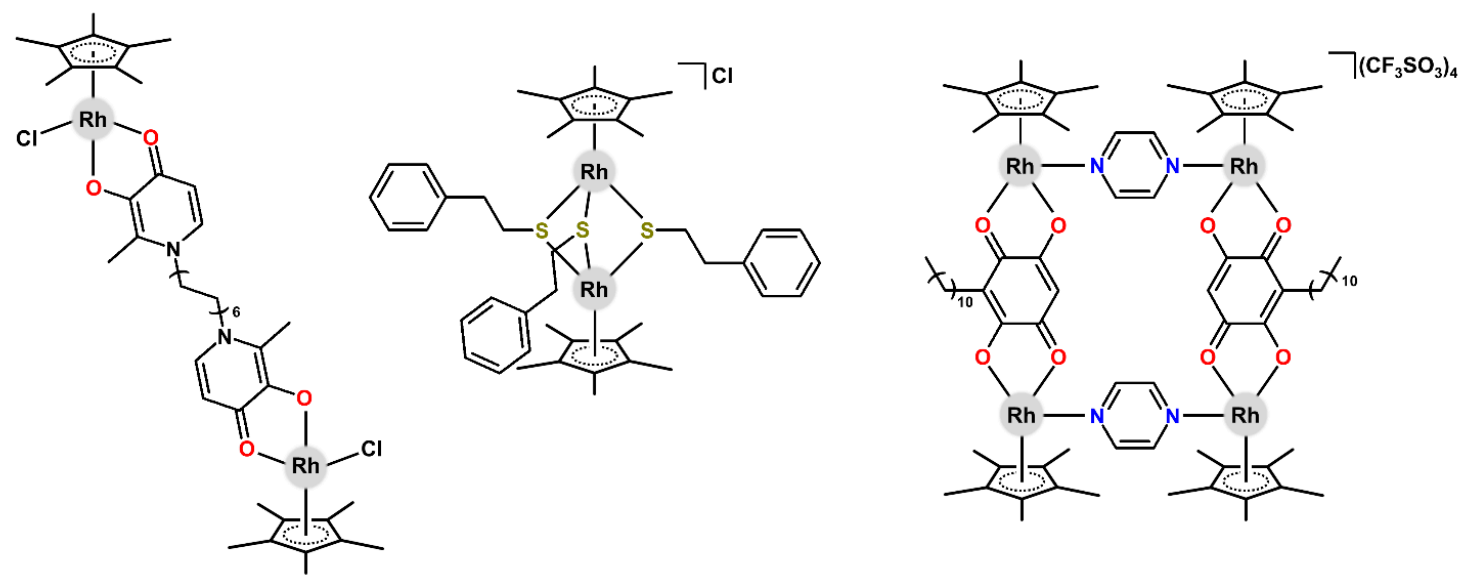

Figure 9. Structural formulas of complexes $\left[\mathrm{Rh}_{2}\left(\mu-\mathrm{mal}^{1}\right)\left(\eta^{5}-\mathrm{Cp}^{*}\right)_{2} \mathrm{Cl}_{2}\right](\mathrm{left}),\left[\mathrm{Rh}_{2}\left(\mu-\mathrm{SR}^{1}\right)_{3}\left(\eta^{5}-\mathrm{Cp}^{*}\right)_{2}\right] \mathrm{Cl}(\mathrm{middle})$ and $\left[\mathrm{Rh} \mathrm{H}_{4}(\mu-\right.$ $\mathrm{dhbq})_{2}(\mu-\mathrm{pyz})_{2}\left(\eta^{5}-\mathrm{Cp}^{*}\right)_{4} \mathrm{l}\left(\mathrm{CF}_{3} \mathrm{SO}_{3}\right)_{4}$ (right), with donor atoms given in red $(\mathrm{O})$, dark yellow $(\mathrm{S})$ or blue $(\mathrm{N})$.

Complexes with terminal $\mathrm{RhCl}_{2}$ moieties bridged by various di- or tritopic ligands were markedly less effective than cisplatin $[100,114,115]$. Further, it has been reported for some $\mathrm{Rh}$ arenyl complexes that multinuclear complexes have superior cytotoxic activity over the mononuclear complexes prepared with the same bridging ligand [116] or with ligands of different topicity $[70,88,112,117,118]$.

\subsection{Thiolato Complexes}

Thiolato complexes (and other chalcogenato complexes) have been widely studied within the field of $\mathrm{Ru}, \mathrm{Rh}, \mathrm{Os}$ and Ir arene/arenyl complexes, as reviewed elsewhere $[7,23,119]$. Regarding Rh(III) thiolato complexes, they were introduced in 2013 thanks to a series of electroneutral dithiolato and ionic trithiolato complexes, such as $\left[\mathrm{Rh}_{2}\left(\mu-\mathrm{SR}^{1}\right)_{2}\left(\eta^{5}-\mathrm{Cp}^{*}\right)_{2} \mathrm{Cl}_{2}\right]$ and $\left[\mathrm{Rh}_{2}\left(\mu-\mathrm{SR}^{1}\right)_{3}\left(\eta^{5}-\mathrm{Cp} \mathrm{p}_{2}\right)_{2}\right] \mathrm{Cl}$ (Figure 9); $\mathrm{SR}^{1}=2$-phenylethanethiolate [109]. Both the representative thiolato complexes showed sub-micromolar cytotoxicity at the A2780 and A2780R cancer cells, which, however, was spoiled by the same effect in the non-cancerous cells, implying their low selectivity (Table 2). The same biological results (high cytotoxicity, low selectivity) have been reported for other Rh thiolato complexes and for chalcogenato ones $[120,121]$.

\subsection{Matallacages}

Similarly to the above-discussed $\mathrm{Rh}$ thiolato complexes, Rh metallacages reported in the literature to date were also highly cytotoxic (usually more than cisplatin) but their selectivity towards the used cancer cells was in most cases lower as compared with the noncancerous cells. As in the case of other platinum metals (i.e., $\mathrm{Ru}$, Os and Ir) known to form anticancer arene/arenyl complexes, all three usual types of metallacages-tetranuclear metallarectangles [110,122], hexanuclear metallaprisms [108,123] and octanuclear metallacubes [111] - have been developed for rhodium.

Complex $\left[\mathrm{Rh}_{4}(\mu \text {-dhbq })_{2}(\mu-p y z)_{2}\left(\eta^{5}-\mathrm{Cp}^{*}\right)_{4}\right]\left(\mathrm{CF}_{3} \mathrm{SO}_{3}\right)_{4}$ (Figure 9) was quite exceptional within organorhodium metallacages, because it was highly selective with ca. two orders of magnitude higher activity at the used cancer cells (prostate DU-145, lung A549 and cervical HeLa) as compared with non-cancerous HEK-293 ones (Table 2); pyz = pyrazine [110]. For this complex, advanced biological studies proved its effect on the cancer cell cycle (increased sub- $\mathrm{G}_{1}$ population), induction of apoptosis of the treated cancer cells, interaction with DNA and a disruptive effect on mitochondria. Similar studies have been performed for complexes of higher nuclearity, such as $\left[\mathrm{Rh}_{6}(\mu \text {-dhbq })_{3}(\mu \text {-tpt })_{2}\left(\eta^{5}-\mathrm{Cp}^{*}\right)_{6}\right]\left(\mathrm{CF}_{3} \mathrm{SO}_{3}\right)_{6}[108]$ and $\left[\mathrm{Rh}_{8}(\mu \text {-dhbq) })_{4}(\mu \text {-tpp })_{2}\left(\eta^{5}-\mathrm{Cp}^{*}\right)_{8}\right]\left(\mathrm{CF}_{3} \mathrm{SO}_{3}\right)_{8}$ [111] derived from the same dinuclear metallaclips (Table 2); tpt = 2,4,6-tris(4-pyridyl)-1,3,5-triazine; tpp = 5,10,15,20-tetra(4-pyridyl)por phyrin. Additionally, the hexanuclear complex $\left[\mathrm{Rh}_{6}(\mu \text {-dhbq })_{3}(\mu \text {-tpt })_{2}\left(\eta^{5}-\mathrm{Cp}^{*}\right)_{6}\right]\left(\mathrm{CF}_{3} \mathrm{SO}_{3}\right)_{6}$ was studied for its in vivo anticancer activity at the tumour-induced C57L6/J mice, where 
this compound showed higher ability to reduce the tumour size than its dinuclear precursor and Ir analogue, and lower toxicity than the mentioned co-studied compounds, because the mice survived for a longer period of time when treated with the mentioned $\mathrm{Rh}$ metallaprisms [108].

\subsection{Heterometallic Complexes}

Most of the formerly reported heterometallic organorhodium-based complexes have been reviewed elsewhere [23,124]. Among them, most representatives belong to the broad family of complexes involving ferrocene-functionalised ligands, in order to mimic ferrocene-derived antimalarial drug ferroquine and improve its anti-microbial activitye.g., [125]. Only a few compounds of such a design have been studied for their anticancer activity $[101,112,126,127]$.

$\mathrm{Rh}, \mathrm{Ru}$ and Ir complexes containing bidentate $\mathrm{N}$-donor 5-ferrocenyldipyrromethene $\left(\mathrm{HFc}^{\mathrm{dpm}}\right)$ were studied for cytotoxicity and the Rh complex $\left[\mathrm{Rh}\left(\eta^{5}-\mathrm{Cp} \mathrm{p}^{*}\right) \mathrm{Cl}\left(\mathrm{Fc}^{\mathrm{dpm}}\right)\right]$ (Figure 10) exceeded the cytotoxic effect of the Ru and Ir counterparts, but it was still lower as compared with cisplatin [126]. Nevertheless, the complexes were deeply bioanalysed for their MoA and it was proved that the organorhodium complex effectively bound the calf thymus DNA (minor-groove intercalation) and bovine serum albumin (BSA), and induced apoptosis in the treated cancer cells. The ferrocene-functionalisation by a bidentate ligand was also used in another series of Rh, Ru and Ir complexes, but without any positive effect of the second metal centre (iron of ferrocene) on the resulting cytotoxicity observed for the Rh complexes [127].
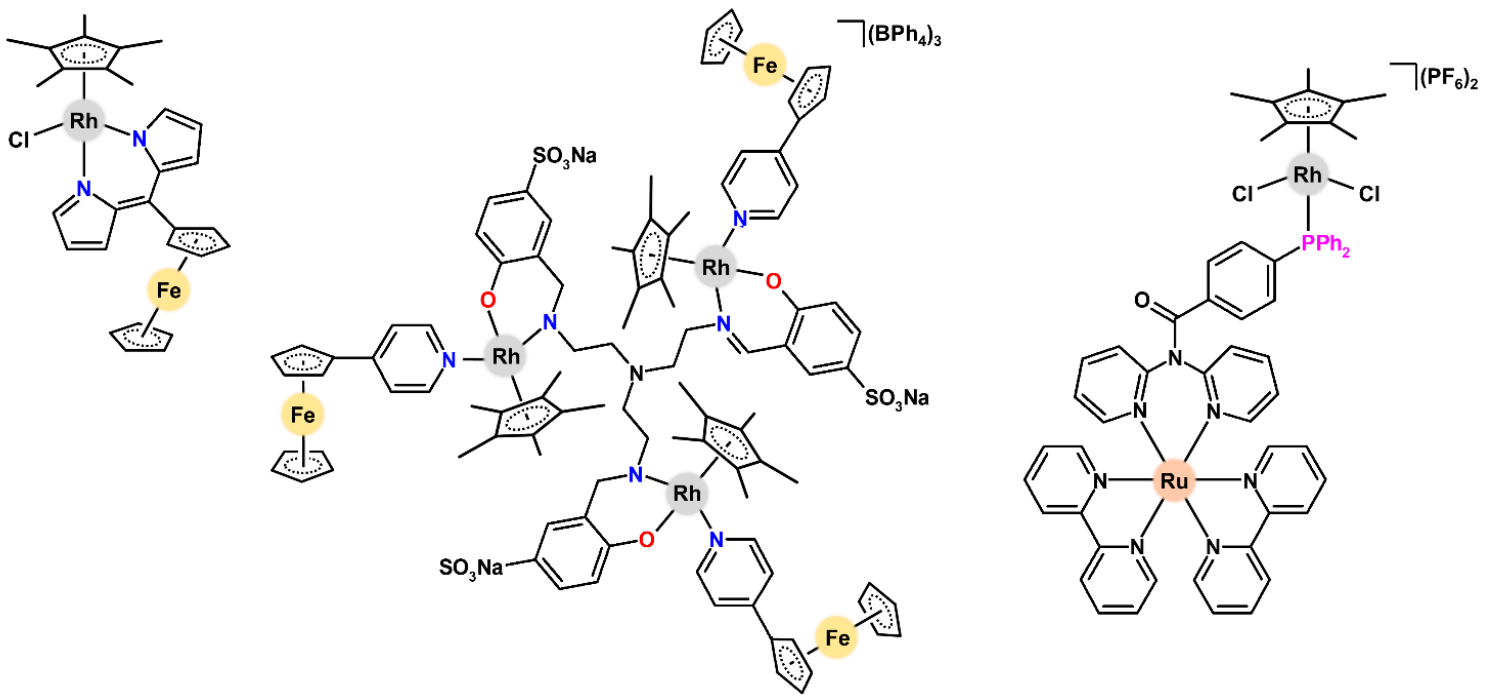

Figure 10. Structural formulas of complexes $\left[\mathrm{Rh}\left(\eta^{5}-\mathrm{C} \mathrm{p}^{*}\right) \mathrm{Cl}(\mathrm{Fc} \mathrm{dpm})\right](\mathrm{left}),\left[\mathrm{Rh}_{3}(\mu\right.$-sai $\left.)\left(\eta^{5}-\mathrm{Cp}^{*}\right)_{3}\left(\mathrm{py}{ }^{\mathrm{Fc}}\right)_{3}\right]\left(\mathrm{BPh}_{4}\right)_{3}(\mathrm{middle})$ and $\left[\mathrm{Cl}_{2}\left(\eta^{5}-\mathrm{Cp} \mathrm{P}^{*}\right) \mathrm{Rh}\left(\mu\right.\right.$-bpy $\left.\left.{ }^{\mathrm{PPh} 3}\right) \mathrm{Ru}(\mathrm{bpy})_{2}\right]\left(\mathrm{PF}_{6}\right)_{2}$ (right), with donor atoms given in blue $(\mathrm{N})$, red $(\mathrm{O})$ or magenta $(\mathrm{P})$.

A different approach was used for complexes $\left[\mathrm{Rh}\left(\eta^{5}-\mathrm{Cp}^{*}\right)\left(\mathrm{py}^{\mathrm{Fe}}\right)\left(\mathrm{sai}^{1}\right)\right] \mathrm{BPh}_{4}$ and $\left[\mathrm{Rh}_{3}(\mu-\right.$ sai) $\left.\left(\eta^{5}-\mathrm{Cp}^{*}\right)_{3}\left(\mathrm{py}^{\mathrm{Fc}}\right)_{3}\right]\left(\mathrm{BPh}_{4}\right)_{3}$ and their Ir analogues, containing 4-ferrocenylpyridine $\left(\mathrm{py}{ }^{\mathrm{Fc}}\right)$ as a monodentate $\mathrm{N}$-donor ferrocene-functionalised ligand; $\mathrm{H}_{3}$ sai, a tripodal sulfonated $\mathrm{N}, \mathrm{O}$-salicylaldiminato ligand [101]. Although mononuclear complex $\left[\mathrm{Rh}\left(\eta^{5}-\mathrm{Cp}^{*}\right)\left(\mathrm{py}^{\mathrm{Fe}}\right)\left(\mathrm{sai}^{1}\right)\right]$ $\mathrm{BPh}_{4}$ was of similar activity $\left(\mathrm{IC}_{50}=31.9 \mu \mathrm{M}\right.$ at the WHCO-1 cells) with complexes containing ferrocene-free pyridines $\left(\mathrm{py}^{\mathrm{n}} ; \mathrm{IC}_{50}=24.9-37.3 \mu \mathrm{M}\right)$, the potency of its trinuclear congener $\left[\mathrm{Rh}_{3}\left(\mu\right.\right.$-sai) $\left.\left(\eta^{5}-\mathrm{Cp}^{*}\right)_{3}\left(\mathrm{py}^{\mathrm{Fc}}\right)_{3}\right]\left(\mathrm{BPh}_{4}\right)_{3}$ (Figure 10) was markedly enhanced $\left(\mathrm{IC}_{50}=0.6 \mu \mathrm{M}\right)$. Interestingly, this was not observed for the other co-studied multinuclear complexes with different pyridines $\left(\mathrm{IC}_{50}=30.6-55.0 \mu \mathrm{M}\right)$. Complex $\left[\mathrm{Rh}_{3}\left(\mu\right.\right.$-sai) $\left(\eta^{5}\right.$ $\left.\left.C \mathrm{p}^{*}\right)_{3}\left(\mathrm{py}^{\mathrm{Fc}}\right)_{3}\right]\left(\mathrm{BPh}_{4}\right)_{3}$ exceeded even the reference drug cisplatin $\left(\mathrm{IC}_{50}=9.2 \mu \mathrm{M}\right)$. The same pyridine derivative $\left(\mathrm{py}^{\mathrm{Fc}}\right)$ was used for the preparation of a series of tetra- and octanuclear Rh, Ir and Ru dendrimers [112]. The organorhodium complexes of higher nuclear- 
ity, such as $\left[\mathrm{Rh}_{8}\left(\mu-\mathrm{saea}^{1}\right)\left(\eta^{5}-\mathrm{Cp}^{*}\right)_{8}\left(\mathrm{py}^{\mathrm{Fc}}\right)_{8}\right]\left(\mathrm{PF}_{6}\right)_{8}$ were more cytotoxic than the mononuclear complex $\left[\mathrm{Rh}\left(\eta^{5}-\mathrm{Cp}^{*}\right)\left(\mathrm{py}^{\mathrm{Fc}}\right)(\right.$ saea $\left.)\right] \mathrm{PF}_{6}$ (Table 2), which, however, was not a general trend for the co-studied Ru and Ir analogues; Hsaea, 2-[(E)-(propylimino)methyl]phenol, saea $^{1}=$ diaminobutane-based dendrimeric ligand bearing 8 terminal saea units.

Regarding other combinations of Rh arenyl moieties with different than iron $\mathrm{d}$ block metals, they are quite rare in the literature. Rh-Ru complex $\left[\mathrm{Cl}_{2}\left(\eta^{5}-\mathrm{Cp}\right) \mathrm{Rh}(\mu-\right.$ bpy $\left.\left.{ }^{\mathrm{PPh} 3}\right) \mathrm{Ru}(\mathrm{bpy})_{2} \mathrm{PF}_{6}\right)_{2}$ (Figure 10) and its $\mathrm{Ru}_{2}$ and $\mathrm{Ru}-\mathrm{Os}$ counterparts were inactive against the A2780, A2780R and A549 cancer cells (Table 2), while the co-studied Ru-Au complexes showed relevant cytotoxicity; bpy ${ }^{\mathrm{PPh} 3}=$ a 4 -methyl-4' - (substituted)-2,2'-bipyridinebased $\mathrm{PPh}_{3}$-bearing linker [113].

The cytotoxic Rh-Pt complex [(Hdto)Pt $\left.(\mu-\mathrm{dto}) \mathrm{Rh}\left(\eta^{5}-\mathrm{Cp}^{*}\right) \mathrm{Cl}\right]$ was an effective inhibitor of proteolytic activities of human $20 \mathrm{~S}$ proteasome and human cathepsins, which was highlighted as advantageous from the Pt precursors. Complex [(Hdto) $\mathrm{Pt}(\mu-\mathrm{dto}) \mathrm{Rh}\left(\eta^{5}-\right.$ $\left.\mathrm{Cp}^{*}\right) \mathrm{Cl}$ induced apoptosis in the treated cancer cells [128].

\section{Discussion}

Anticancer organorhodium complexes have been in many cases studied together with their $\operatorname{Ir}(\mathrm{III}), \mathrm{Ru}(\mathrm{II})$ and $\mathrm{Os}(\mathrm{II})$ analogues, which allowed us to compare compounds differing in the used metal. In this manner, even the first anticancer half-sandwich Rh complex $\left[\mathrm{Rh}\left(\eta^{5}-\mathrm{Cp}^{*}\right)(\mathrm{pta}) \mathrm{Cl}_{2}\right]$ (Figure 2, Table 1) was more in vitro cytotoxic than the co-studied complexes $\left[\mathrm{M}\left(\eta^{6}\right.\right.$-pcym $\left.)(\mathrm{pta}) \mathrm{Cl}_{2}\right](\mathrm{M}=\mathrm{Ru}$ (for RAPTA-C) or Os), especially against the A549 (lung carcinoma) and T47D (breast carcinoma) human cancer cells [30]. Similarly, another cutting-edge work reported on anticancer organorhodium complexes showed complex $\left[\mathrm{Rh}\left(\eta^{5}-\mathrm{Cp}^{*}\right)(\mathrm{dppz}) \mathrm{Cl} \mathrm{CF}_{3} \mathrm{SO}_{3}\right.$ (Figure 2, Table 1) as being more cytotoxic than the Ir counterpart and cisplatin.

Two acridine-containing salicylaldimine (Hsalac, Figure 4) and 2-pyridylimine (pyac) ligands were used for the preparation of a series of $\mathrm{Ru}, \mathrm{Rh}$, Os and Ir complexes, allowing the evaluation of the metal-dependence within these anticancer complexes [66]. Both the electroneutral and ionic complexes $\left[\mathrm{Rh}\left(\eta^{5}-\mathrm{Cp} \mathrm{p}^{*}\right) \mathrm{Cl}(\mathrm{salac})\right]$ and $\left[\mathrm{Rh}\left(\eta^{5}-\mathrm{Cp}^{*}\right)(\mathrm{pyac}) \mathrm{Cl}\right] \mathrm{BPh}_{4}$ were more cytotoxic to the HL60 human promyelocytic leukaemia cell line than the analogues and cisplatin (Figure 11).
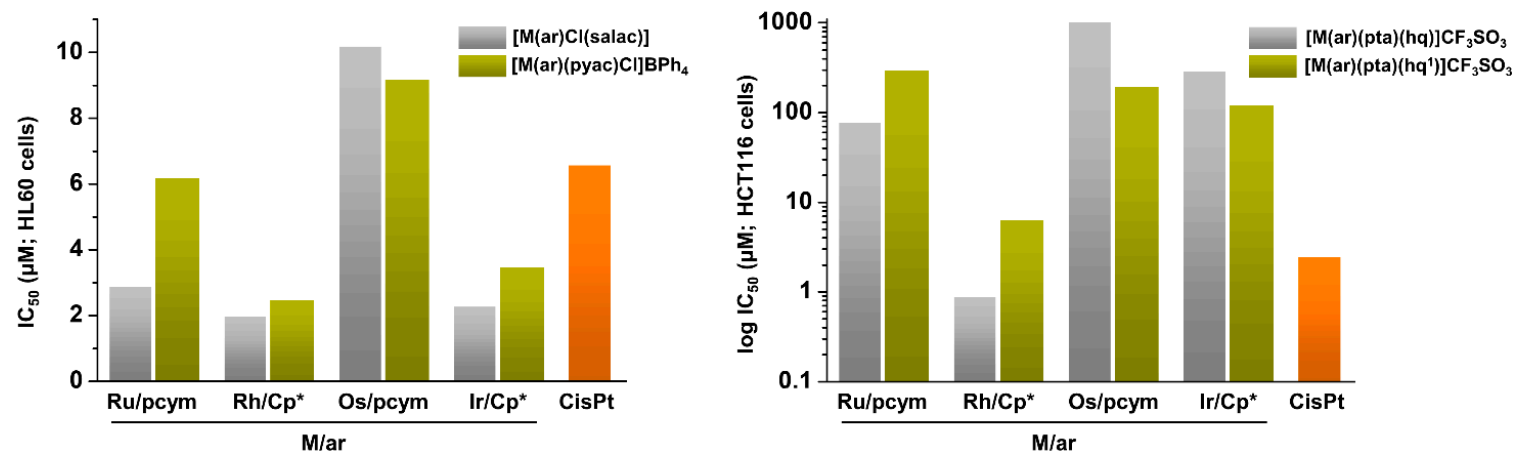

Figure 11. Comparison of in vitro antiproliferative activity of complexes $[\mathrm{M}(\operatorname{ar}) \mathrm{Cl}(\mathrm{salac})]$ and $[\mathrm{M}(\mathrm{ar})(\mathrm{pyac}) \mathrm{Cl}] \mathrm{BPh}$ in the HL60 human promyelocytic leukaemia cell line (left), and of complexes $\left[\mathrm{M}\left(\eta^{5}-\mathrm{Cp}^{*}\right)(\mathrm{pta})(\mathrm{hq}) \mathrm{CF}_{3} \mathrm{SO}_{3}\right.$ and $\left[\mathrm{Rh}\left(\eta^{5}-\mathrm{Cp}^{*}\right)(\mathrm{pta})\left(\mathrm{hq}^{1}\right)\right] \mathrm{CF}_{3} \mathrm{SO}_{3}$ against the HCT116 colorectal carcinoma cell line. Hsalac $=$ acridine-containing salicylaldimine ligand, pyac $=$ acridine-containing 2-pyridylimine ligand; $\mathrm{Hhq}=8$-hydroxyquinoline, $\mathrm{Hhq}^{1}=5$-chloro-7-iodo-8-

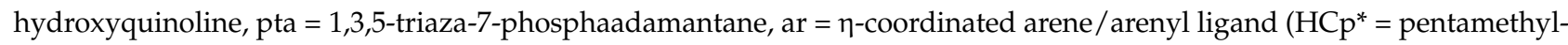
cyclopentadiene, pcym $=p$-cymene), $\mathrm{CisPt}=$ cisplatin.

Besides the 2D cultures of adherent cancer cells, complex $\left[\mathrm{Rh}\left(\eta^{5}-\mathrm{C} \mathrm{p}^{*}\right) \mathrm{Cl}(\right.$ thpy)] (Figure 5) was also more cytotoxic than the $\mathrm{Ru}$ and Ir analogues in the advanced model using the HCT-116 multicellular spheroids [50].

Similar results, showing organorhodium complexes of various types to be more cytotoxic than their analogues derived from different metals (i.e., $\mathrm{Ru}$, Os and Ir), have been 
reported in several other works [32,34,40,41,44,66,95,102,104,107] (Figure 11). However, this could not be claimed, based on the results reported to date in the literature, as a general trend for all Rh complexes and their Ru, Os and Ir analogues, because many other Rh complexes were determined to be less anticancer active than their congeners. For example, Rh complexes with curcumin-based ligands were more cytotoxic than their Ir counterparts, but markedly less potent than similar Ru-cur complex [43]. Unclear dependence of the $\mathrm{IC}_{50}$ values was also reported for a series of $\mathrm{Rh}, \mathrm{Ru}, \mathrm{Os}$ and Ir complexes containing thiomaltol [49]. Additionally, other series of complexes reported on $\mathrm{Rh}$ ones with lower anticancer activity as compared with all of their co-studied $\mathrm{Ru}, \mathrm{Os}$ and/or Ir counterparts $[42,61,62,68]$.

Complex $\left[\mathrm{Rh}\left(\eta^{5}-\mathrm{Cp}^{\text {as }}\right)(\mathrm{CO})_{2}\right]$ (Figure 8, Table 2) exhibited comparable cytotoxicity with the Co and Mo counterparts and higher potency when compared with the Mn complex (Figure 12) [106]. In addition, higher inhibitory activity of cyclooxygenase-1 was observed for the Rh complex in comparison with the mentioned Co, Mo and Mn ones.

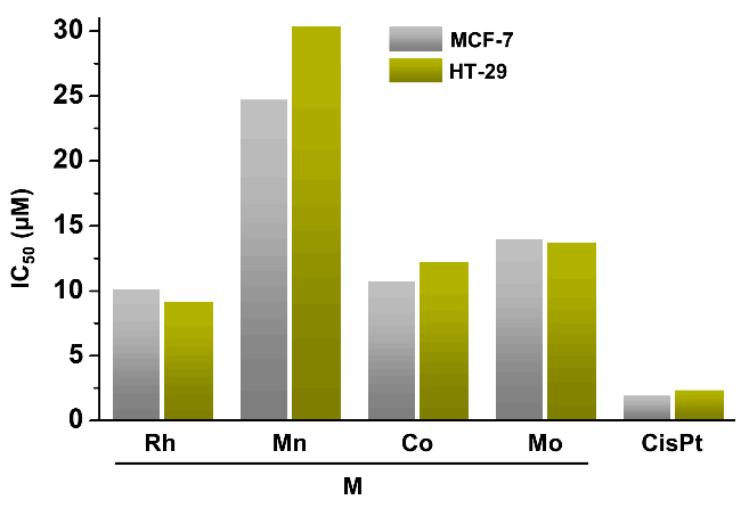

Figure 12. Comparison of in vitro antiproliferative activity of complexes $\left[\mathrm{M}\left(\eta^{5}-\mathrm{Cp} \mathrm{p}^{\mathrm{as}}\right)(\mathrm{CO})_{2}\right]$ (see Figure 8 for the structural formula of the Rh complex) against the MCF-7 breast carcinoma and HT-29 colon carcinoma cell lines. $\mathrm{Cp}^{\text {as }}=($ cyclopenta-1,3-dienyl)propyl-2-acetoxybenzoate, $\mathrm{CisPt}=$ cisplatin .

Solution behaviour. One of the most important properties of anticancer complexes is their behaviour (stability) under aqueous conditions. For example, one of the first anticancer active organorhodium complexes, $\left[\mathrm{Rh}\left(\eta^{5}-\mathrm{Cp}^{*}\right)(\mathrm{pta}) \mathrm{Cl}_{2}\right]$ (Figure 2, Table 1), was less stable than the $\mathrm{Ru}$ (RAPTA-C) and Os counterparts in a $120 \mathrm{mM} \mathrm{NaCl}$ aqueous solution [30].

Pioneer chlorido complexes $\left[\mathrm{Rh}\left(\eta^{5}-\mathrm{Cp}^{*}\right)(\mathrm{pp}) \mathrm{Cl}\right] \mathrm{CF}_{3} \mathrm{SO}_{3}$ hydrolysed under aqueous conditions to dicationic aqua species [36]. Later it was proved for organorhodium complexes of this type that the hydrolysis rate depended on the used cyclopentadienyl ring, following the order of $\mathrm{Cp}^{*}<\mathrm{Cp}^{\mathrm{ph}}<\mathrm{C} \mathrm{p}^{\text {bph }}[56]$.

Advanced solution behaviour studies of similar complexes, specifically the $\left[\mathrm{Rh}\left(\eta^{5}-\right.\right.$ $\left.\left.\mathrm{Cp}^{*}\right)(n \mathrm{hq})\left(\mathrm{H}_{2} \mathrm{O}\right)\right]^{+}$species, showed higher $\mathrm{pK}$ values and higher affinity towards the chloride ions in comparison with the co-studied $\mathrm{Ru}$ complexes; $n \mathrm{Hhq}=$ quinolin-8-ol (Figure 4) or its derivatives [85]. In this study, a decrease of lipophilicity with decreasing chloride ion concentrations (causing a higher aquation rate) was observed and resulted in higher lipophilicity for the Rh complexes than for the $\mathrm{Ru}$ analogues.

In the case of complex $\left[\mathrm{Rh}\left(\eta^{5}-\mathrm{Cp}^{*}\right) \mathrm{Cl}(\right.$ cur $\left.)\right]$, the used chelating $O, O$-donor ligand curcumin (Figure 4, Table 1) released in solution, which was claimed to be beneficial for the complex, usable as a drug-delivery system [90,91]. Accordingly, complexes derived from $\mathrm{O}, \mathrm{O}$-donor ligands (flavonols or pyrones) were less stable in aqueous solutions than complexes containing $O, S$-donor ligands (2-aryl-4-thiopyrones or thiomaltol) [48,49].

Mechanism of action. One of the first studies dealing with MoA of half-sandwich $\mathrm{Rh}$ complexes showed that complexes $\left[\mathrm{Rh}\left(\eta^{5}-\mathrm{C} \mathrm{p}^{*}\right)(\mathrm{pp}) \mathrm{Cl}\right] \mathrm{CF}_{3} \mathrm{SO}_{3}$ effectively affected mitochondria (impairment of respiration, cytochrome c release) and induced apoptosis accompanied by high ROS population in the treated Jurkat leukaemia cells [63]. Similar processes (especially the induction of apoptosis and ROS formation) were observed for other 
organorhodium complexes [42,45]. In some cases, Rh complexes modified the cell cycle of the treated cancer cells $[45,54,55]$.

Other complexes were reported as targeting the DNA molecule—e.g., see $[36,45,55,63,100]$ - thereby inducing the cell death by a similar mechanism as that of conventional $\mathrm{Pt}$ anticancer drugs [1-4]. Within a series of $\mathrm{Rh}, \mathrm{Ru}$ and Os complexes with $\mathrm{O}, \mathrm{O}$-coordinated 3-hydroxyflavonols (Hfla; Figure 4, Table 1), the Rh complexes bound DNA differently (preferably to $5^{\prime}$-dATP) than the Ru and Os ones (5'-dGTP) [44]. This was also reported for $\mathrm{Rh}$ and Ru complexes involving various 1,3-dioxoindan-2-carboxamides [93]. Besides the interaction with DNA, these complexes readily inhibited topo II $\alpha$, which was not observed for the free ligands at the same concentration level. As a consequence of the topo II $\alpha$ inhibition, the cell cycle of the treated cells was also modified.

The topo II $\alpha$ inhibition was also reported for other organorhodium complexes $[48,49]$. In contrast with many $\mathrm{Rh}$ arenyl complexes inducing the ROS formation, complexes involving 2-aryl-4-thiopyrone derivatives did not generate ROS, and their MoA was linked exclusively to the topo II $\alpha$ inhibition [48]. Another enzyme, cathepsin B, was inhibited by the steroidal conjugate $\left[\mathrm{Rh}\left(\eta^{5}-\mathrm{Cp}^{*}\right) \mathrm{Cl}\left(\mathrm{ppy}^{1}\right)\right]$ involving the ppy-based ligand functionalised by 17- $\alpha$-[2-phenylpyridyl-4-ethynyl]-19-nortestosterone (ppy ${ }^{1}$; Figure 6, Table 1) [52].

Several research groups have explained the relationships between the catalytic properties of specific $\mathrm{Rh}(\mathrm{III})$ half-sandwich complexes and their biological activity through the transfer-hydrogenation catalysis of naturally occurring substrates [24,25,38,129-131], as also reported by Sadler and co-workers for structurally similar $\mathrm{Ru}$, Os and Ir arene/arenyl complexes at both in vitro and in cellulo levels [132-134]. Complexes $\left[\mathrm{Rh}\left(\eta^{5}-\mathrm{Cp}^{\mathrm{x}}\right)(\mathrm{L}) \mathrm{Cl}\right] \mathrm{PF}_{6}$ catalysed the reduction of $\mathrm{NAD}^{+}$to $\mathrm{NADH}$ and of pyruvate to lactate, both using formate as a hydride source; $\mathrm{L}=\mathrm{en}$, bpy, phen or tfen (Figure 3); $\mathrm{Cp}^{\mathrm{x}}=\mathrm{Cp}^{*}, \mathrm{Cp}^{\mathrm{ph}}$ or $\mathrm{Cp} \mathrm{p}^{\mathrm{bph}}$ [38]. No clear dependence was observed between the catalytic efficacy and cytotoxicity, as exemplified for complexes $\left[\mathrm{Rh}\left(\eta^{5}-\mathrm{Cp}^{*}\right)(\mathrm{bpy}) \mathrm{Cl}\right] \mathrm{PF}_{6}\left(\mathrm{TOF}=37.4 \mathrm{~h}^{-1}, \mathrm{IC}_{50}=64.0 \mu \mathrm{M}\right)$ and $\left[\mathrm{Rh}\left(\eta^{5}-\mathrm{Cp}^{\mathrm{bph}}\right)(\mathrm{phen}) \mathrm{Cl}\right] \mathrm{PF}_{6}\left(\mathrm{TOF}=8.2 \mathrm{~h}^{-1}, \mathrm{IC}_{50}=14.7 \mu \mathrm{M}\right)$-given for the $\mathrm{NAD}^{+}$reduction and for the A2780 cells (Table 1). Despite that, some of the studied complexes showed improved activity towards the A2780 cells when administered with formate. A similar complex, $\left[\mathrm{Rh}\left(\eta^{5}-\mathrm{Cp}^{\mathrm{x}}\right)\right.$ (bqui)Cl] (Figure 6, Table 1), catalysed the NADH oxidation and induced the formation of ROS in the treated cancer cells [56].

Replacement of the chlorido ligand. In some cases, Rh arenyl chlorido complexes were studied with similar complexes containing different monodentate ligands. Complexes $\left[\mathrm{Rh}\left(\eta^{5}-\mathrm{Cp}^{*}\right)(\mathrm{pp}) \mathrm{X}\right]\left(\mathrm{CF}_{3} \mathrm{SO}_{3}\right)_{\mathrm{n}}$ with tetramethyl thiourea $(\mathrm{pp}=\mathrm{dpq}$, dppz and dppn; Figure 2, Table 1) were of similar cytotoxicity to their chlorido counterparts, while complexes $\left[\mathrm{Rh}\left(\eta^{5}-\mathrm{Cp}^{*}\right)(\mathrm{dppz})(\mathrm{bzth})\right] \mathrm{CF}_{3} \mathrm{SO}_{3}$ (Figure 7$)$ and $\left[\mathrm{Rh}\left(\eta^{5}-\mathrm{Cp}^{*}\right)(\mathrm{dppz})(\mathrm{npth})\right] \mathrm{CF}_{3} \mathrm{SO}_{3}$ exceeded the potency of the co-studied chlorido analogues at the MCF-7 cells, which, however, was not observed at the second cell line, A2780 (Figure 13, Tables 1 and 2) [36]. These two complexes (with bzth and npth) interacted with DNA to a lower extent than other complexes. In contrast with the chlorido complexes, these complexes with the monodentate $S$-donor ligand did not hydrolyse the aqua species.

The py-based complexes $\left[\mathrm{Rh}\left(\eta^{5}-\mathrm{Cp}^{\mathrm{x}}\right)(\mathrm{py})(\mathrm{bqui})\right] \mathrm{NO}_{3}$ showed higher cytotoxicity than the chlorido ones in the A549 cells, but not in the A2780 cells (Figure 13, Tables 1 and 2) [56]. In contrast to the chlorido complexes (ROS inducers), complex $\left[\mathrm{Rh}\left(\eta^{5}-\mathrm{Cp}{ }^{\mathrm{bph}}\right)(\mathrm{py})(\mathrm{bqui})\right] \mathrm{NO}_{3}$ (Figure 7) untypically acted in the performed in-cell experiment as an ROS scavenger. Additionally, of importance, the pyridine complexes interacted much more slowly with NADH and GSH than the chlorido ones, which could be linked with different cytotoxicity of these two types of the studied complexes, differing in the monodentate ligand used. Similarly, higher stability of the thiomaltol-based complexes was reported for those containing the monodentate $\mathrm{N}$-donor ligand 1-methylimidazole instead of the chlorido ligand [49]. 

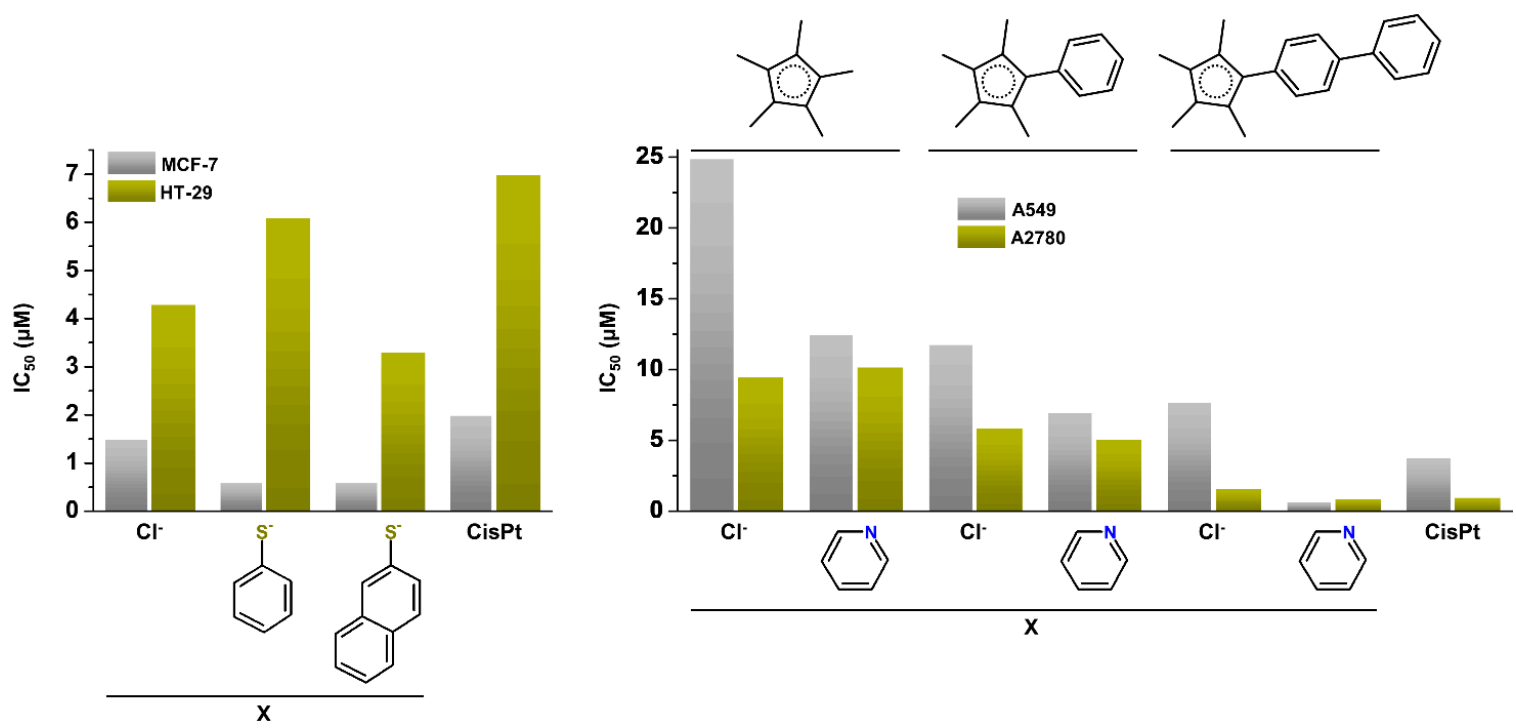

Figure 13. Comparison of in vitro antiproliferative activity of complexes $\left[\mathrm{Rh}\left(\eta^{5}-\mathrm{Cp}^{*}\right)(\mathrm{dppz}) \mathrm{X}\right] \mathrm{CF}_{3} \mathrm{SO}_{3}\left(l e f t ; \mathrm{X}=\mathrm{Cl}^{-}\right.$, benzenethiolate or naphthalene-2-thiolate) against the MCF-7 breast carcinoma and HT-29 colon carcinoma cell lines, and complexes $\left[\mathrm{Rh}\left(\eta^{5}-\mathrm{C} \mathrm{p}^{\mathrm{x}}\right)(\mathrm{bqui}) \mathrm{X}\right] \mathrm{NO}_{3}$ (right; $\mathrm{X}=\mathrm{Cl}^{-}$or pyridine) against the A549 lung carcinoma and A2780 ovarian carcinoma

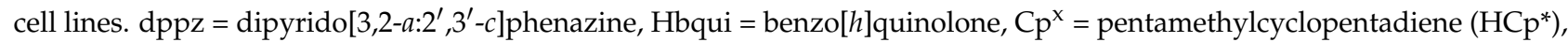
(2,3,4,5-tetramethylcyclopenta-2,4-dien-1-yl)benzene $\left(\mathrm{HC}^{\mathrm{ph}}\right)$ or 4-(2,3,4,5-tetramethylcyclopenta-2,4-dien-1-yl)biphenyl $\left(\mathrm{HCp}^{\mathrm{bph}}\right), \mathrm{CisPt}=$ cisplatin

Complexes of the general formula $\left[R h\left(\eta^{5}-\mathrm{Cp}^{*}\right)(\mathrm{dpa}) \mathrm{X}_{\mathrm{PF}_{6}}\right.$ were studied in order to investigate the effect of different halogenido ligands on the resulting cytotoxicity [81]. As mentioned above, the iodido complex was more cytotoxic than the bromido and chlorido analogues, which correlated with the trend of lipophilicity $(\log P)$. In the same work, complexes $\left[\mathrm{Rh}\left(\eta^{5}-\mathrm{Cp}^{*}\right)(\mathrm{dpa})(\mathrm{pb})\right] \mathrm{PF}_{6}$ and $\left[\mathrm{Rh}\left(\eta^{5}-\mathrm{Cp}^{*}\right)(\mathrm{dpa})(\mathrm{vp})\right] \mathrm{PF}_{6}$ containing O-donor HDAC inhibitors phenylbutyrate $(\mathrm{pb})$ and valproate $(\mathrm{vp})$ were, similarly to the mentioned bromido and chlorido complexes, inactive in the A2780 cell line.

Complexes $\left[\mathrm{Rh}\left(\eta^{5}-\mathrm{Cp}^{*}\right)(\mathrm{pta})(\mathrm{hq})\right] \mathrm{CF}_{3} \mathrm{SO}_{3}$ (Figure 7 and Table 2) and $\left[\mathrm{Rh}\left(\eta^{5}-\mathrm{Cp} \mathrm{p}^{*}\right)(\mathrm{pta})\right.$ $\left.\left(\mathrm{hq}^{1}\right)\right] \mathrm{CF}_{3} \mathrm{SO}_{3}$ can be considered as derivatives of $\left[\mathrm{Rh}\left(\eta^{5}-\mathrm{Cp}^{*}\right)(\mathrm{pta}) \mathrm{Cl}_{2}\right]$ with the bidentate 8hydroxyquinolines (hq or hq ${ }^{1}$ ) instead of two chlorides [30,102]. This allows a comparison of the biological activity of both types of complexes, which clearly proved that utilisation of bidentate ligands instead of two chlorido ligands was beneficial for organorhodium complexes. In particular, complexes $\left[\mathrm{Rh}\left(\eta^{5}-\mathrm{Cp} \mathrm{p}^{*}\right)(\mathrm{pta})(\mathrm{hq})\right] \mathrm{CF}_{3} \mathrm{SO}_{3}\left(\mathrm{IC}_{50}=0.9 \mu \mathrm{M}\right)$ and $\left[\mathrm{Rh}\left(\eta^{5}-\mathrm{Cp}^{*}\right)(\mathrm{pta})\left(\mathrm{hq}^{1}\right)\right] \mathrm{CF}_{3} \mathrm{SO}_{3}\left(\mathrm{IC}_{50}=6.4 \mu \mathrm{M}\right)$ exhibited markedly higher antiproliferative activity than $\left[\mathrm{Rh}\left(\eta^{5}-\mathrm{Cp}^{*}\right)(\mathrm{pta}) \mathrm{Cl}_{2}\right]\left(\mathrm{IC}_{50}=380 \mu \mathrm{M}\right)$-studied in colon carcinoma cells.

Regarding homometallic and heterometallic multinuclear complexes, their biological activity has very recently been discussed elsewhere [23].

\section{Conclusions}

Since significant advances were made for anticancer ruthenium-based compounds, structurally similar complexes derived from the platinum metals Rh, Os and Ir have also become of interest for bioinorganic and bioorganometallic chemists. As a result, $\mathrm{Rh}$ analogues of known anticancer Ru complexes have been developed and studied for their biological activity. For example, the pioneering Rh arenyl complex $\left[\mathrm{Rh}\left(\eta^{5}-\mathrm{Cp} *(\mathrm{pta}) \mathrm{Cl}_{2}\right]\right.$ is a Rh-based analogue of the Ru complex RAPTA-C. In the last decade, anticancer Rh complexes have represented an independent, widely investigated family of bioinorganic compounds of various structural types.

In this review, the current knowledge regarding anticancer half-sandwich rhodium(III) complexes is described and discussed. The results imply that the development of organorho dium compounds is a viable strategy for bioorganometallic chemists, because in many 
cases it was Rh complexes that showed the highest anticancer activities when compared with their Ru, Os and Ir analogues. Additionally, of importance for the future studies, organorhodium arenyl complexes also showed relevant advantages in various processes connected with their MoA, not only over the conventional platinum-based drugs, but also over the structurally similar half-sandwich complexes derived from other platinum-metals (i.e., $\mathrm{Ru}$, Os and $\mathrm{Ir}$ ).

Most representatives so far have been reported for mononuclear chlorido complexes bearing various bidentate ligands, whose donor set seems to be a crucial factor for pharmacokinetics (e.g., stability under the aqueous conditions), as discussed for complexes involving various $\mathrm{O}, \mathrm{O}$-donor chelating ligands and their more stable analogues with similar $\mathrm{O}, \mathrm{S}$-donor ligands or with various $\mathrm{N}, \mathrm{N}$-donor ones. Regarding MoA, it has not been fully understood for the individual structural types of Rh arenyl complexes, and thus further studies are required for formerly reported or newly developed $\mathrm{Rh}$ arenyl compounds in order to unravel the events occurring under physiological conditions.

Author Contributions: Conceptualization, K.M., L.M. and P.Š.; Methodology, K.M., L.M. and P.Š.; Validation, K.M., L.M. and P.Š.; Resources, K.M., L.M. and P.Š.; Data Curation, K.M., L.M. and P.Š.; Writing-Original Draft Preparation, K.M., L.M. and P.Š.; Writing-Review \& Editing, K.M., L.M. and P.Š.; Visualization, L.M. and P.Š.; Supervision, P.Š.; Project Administration, P.Š.; Funding Acquisition, K.M., L.M. and P.Š. All authors have read and agreed to the published version of the manuscript.

Funding: This research was funded by Palacký University in Olomouc (project PrF_2021_009).

Institutional Review Board Statement: Not applicable.

Informed Consent Statement: Not applicable.

Data Availability Statement: Not applicable.

Acknowledgments: The authors gratefully thank Radka Krrikavová for the careful reading of the text and for valuable comments.

Conflicts of Interest: The authors declare no conflict of interest.

\section{References}

1. Kelland, L. The resurgence of platinum-based cancer chemotherapy. Nat. Rev. Cancer 2007, 7, 573-584. [CrossRef] [PubMed]

2. Florea, A.M.; Büsselberg, D. Cisplatin as an Anti-Tumor Drug: Cellular Mechanisms of Activity, Drug Resistance and Induced Side Effects. Cancers 2011, 3, 1351-1371. [CrossRef] [PubMed]

3. Shen, D.W.; Pouliot, L.M.; Hall, M.D.; Gottesman, M.M. Cisplatin resistance: A cellular self-defense mechanism resulting from multiple epigenetic and genetic changes. Pharmacol. Rev. 2012, 64, 706-721. [CrossRef] [PubMed]

4. Johnstone, T.C.; Suntharalingam, K.; Lippard, S.J. The Next Generation of Platinum Drugs: Targeted Pt(II) Agents, Nanoparticle Delivery, and Pt(IV) Prodrugs. Chem. Rev. 2016, 116, 3436-3486. [CrossRef]

5. Kenny, R.G.; Marmion, C.J. Toward Multi-Targeted Platinum and Ruthenium Drugs-A New Paradigm in Cancer Drug Treatment Regimens? Chem. Rev. 2019, 119, 1058-1137. [CrossRef]

6. Štarha, P.; Vančo, J.; Trávníček, Z. Platinum iodido complexes: A comprehensive overview of anticancer activity and mechanisms of action. Coord. Chem. Rev. 2019, 380, 103-135. [CrossRef]

7. Sigel, A.; Sigel, H.; Freisinger, E.; Sigel, R.K.O. (Eds.) Metallo-Drugs: Development and Action of Anticancer Agents, 1st ed.; Metal Ions in Life Sciences; De Gruyter: Berlin, Germany, 2018; Volume 18.

8. Anthony, E.J.; Bolitho, E.M.; Bridgewater, H.E.; Carter, O.W.L.; Donnelly, J.M.; Imberti, C.; Lant, E.C.; Lermyte, F.; Needham, R.J.; Palau, M.; et al. Metallodrugs are unique: Opportunities and challenges of discovery and development. Chem. Sci. 2020, 11, 12888-12917. [CrossRef]

9. Meier-Menches, S.M.; Gerner, C.; Berger, W.; Hartinger, C.G.; Keppler, B.K. Structure-activity relationships for ruthenium and osmium anticancer agents-Towards clinical development. Chem. Soc. Rev. 2018, 47, 909-928. [CrossRef]

10. Leung, C.H.; Zhong, H.J.; Chan, D.S.H.; Ma, D.L. Bioactive iridium and rhodium complexes as therapeutic agents. Coord. Chem. Rev. 2013, 257, 1764-1776. [CrossRef]

11. Fanelli, M.; Formica, M.; Fusi, V.; Giorgi, L.; Micheloni, M.; Paoli, P. New trends in platinum and palladium complexes as antineoplastic agents. Coord. Chem. Rev. 2016, 310, 41-79. [CrossRef]

12. Hanif, H.; Babak, M.V.; Hartinger, C.G. Development of anticancer agents: Wizardry with osmium. Drug Discov. Today 2014, 19, 1640-1648. [CrossRef]

13. Štarha, P.; Trávníček, Z. Non-platinum complexes containing releasable biologically active ligands. Coord. Chem. Rev. 2019, 395, 130-145. [CrossRef] 
14. Alessio, E. Thirty Years of the Drug Candidate NAMI-A and the Myths in the Field of Ruthenium Anticancer Compounds: A Personal Perspective. Eur. J. Inorg. Chem. 2017, 2017, 1549-1560. [CrossRef]

15. Wernitznig, D.; Kiakos, K.; Del Favero, G.; Harrer, N.; Machat, H.; Osswald, A.; Jakupec, M.A.; Wernitznig, A.; Sommergruber, W.; Keppler, B.K. First-in-class ruthenium anticancer drug (KP1339/IT-139) induces an immunogenic cell death signature in colorectal spheroids in vitro. Metallomics 2019, 11, 1044-1048. [CrossRef]

16. Monro, S.; Colón, K.L.; Yin, H.; Roque, J., III; Konda, P.; Gujar, S.; Thummel, R.P.; Lilge, L.; Cameron, C.G.; McFarland, S.A. Transition Metal Complexes and Photodynamic Therapy from a Tumor-Centered Approach: Challenges, Opportunities, and Highlights from the Development of TLD1433. Chem. Rev. 2019, 119, 797-828. [CrossRef] [PubMed]

17. Notaro, A.; Gasser, G. Monomeric and dimeric coordinatively saturated and substitutionally inert Ru(II) polypyridyl complexes as anticancer drug candidates. Chem. Soc. Rev. 2017, 46, 7317-7337. [CrossRef]

18. Zeng, L.; Gupta, P.; Chen, Y.; Wang, E.; Ji, L.; Chao, H.; Chen, Z.S. The development of anticancer ruthenium(II) complexes: From single molecule compounds to nanomaterials. Chem. Soc. Rev. 2017, 46, 5771-5804. [CrossRef]

19. Song, G.Y.; Li, X.W. Substrate Activation Strategies in Rhodium(III)-Catalyzed Selective Functionalization of Arenes. Acc. Chem. Rev. 2015, 48, 1007-1020. [CrossRef] [PubMed]

20. Shan, J.J.; Li, M.W.; Allard, L.F.; Lee, S.S.; Flytzani-Stephanopoulos, M. Mild oxidation of methane to methanol or acetic acid on supported isolated rhodium catalysts. Nature 2017, 551, 605-608. [CrossRef]

21. Chen, L.; Quan, H.; Xu, Z.; Wang, H.; Xia, Y.; Lou, L.; Yang, W. A modular biomimetic strategy for the synthesis of macrolide P-glycoprotein inhibitors via Rh-catalyzed C-H activation. Nat. Commun. 2020, 11, 2151. [CrossRef]

22. Wang, Z.; Yin, J.; Zhou, F.; Liu, Y.; You, J. Multicomponent Reactions of Pyridines To Give Ring-Fused Pyridiniums: In Situ Activation Strategy Using 1,2-Dichloroethane as a Vinyl Equivalent. Angew. Chem. Int. Ed. 2019, 58, 254-258. [CrossRef]

23. Štarha, P. Multinuclear biologically active Ru, Rh, Os and Ir arene complexes. Coord. Chem. Rev. 2021, 431, 213690. [CrossRef]

24. Soldevila-Barreda, J.J.; Sadler, P.J. Approaches to the design of catalytic metallodrugs. Curr. Opin. Chem. Biol. 2015, 25, 172-183. [CrossRef] [PubMed]

25. Soldevila-Barreda, J.J.; Metzler-Nolte, N. Intracellular Catalysis with Selected Metal Complexes and Metallic Nanoparticles: Advances toward the Development of Catalytic Metallodrugs. Chem. Rev. 2019, 119, 829-869. [CrossRef] [PubMed]

26. Yang, G.J.; Wang, W.; Mok, S.W.F.; Wu, C.; Law, B.Y.K.; Miao, X.M.; Wu, K.J.; Zhong, H.J.; Wong, C.Y.; Wong, V.K.W.; et al. Selective inhibition of lysine-specific demethylase 5A (KDM5A) using a rhodium (III) complex for triple-negative breast cancer therapy. Angew. Chem. Int. Ed. 2018, 57, 13091-13095. [CrossRef]

27. Threatt, S.D.; Synold, T.W.; Wu, J.; Barton, J.K. In vivo anticancer activity of a rhodium metalloinsertor in the HCT116 xenograft tumor model. Proc. Natl. Acad. Sci. USA 2020, 117, 17535-17542. [CrossRef]

28. Liang, J.; Levina, A.; Jia, J.; Kappen, P.; Glover, C.; Johannessen, B.; Lay, P.A. Reactivity and Transformation of Antimetastatic and Cytotoxic Rhodium(III)-Dimethyl Sulfoxide Complexes in Biological Fluids: An XAS Speciation Study. Inorg. Chem. 2019, 58, 4880-4893. [CrossRef]

29. Fan, R.; Bian, M.; Hu, L.; Wukun, L. A new rhodium(I) NHC complex inhibits TrxR: In vitro cytotoxicity and in vivo hepatocellular carcinoma suppression. Eur. J. Med. Chem. 2019, 183, 111721. [CrossRef]

30. Dorcier, A.; Ang, W.H.; Bolano, S.; Gonsalvi, L.; Juillerat-Jeannerat, L.; Laurenczy, G.; Peruzzini, M.; Phillips, A.D.; Zanobini, F.; Dyson, P.J. In Vitro Evaluation of Rhodium and Osmium RAPTA Analogues: The Case for Organometallic Anticancer Drugs Not Based on Ruthenium. Organometallics 2006, 25, 4090-4096. [CrossRef]

31. Pruchnik, H.; Latocha, M.; Zielinska, A.; Pruchnik, F.P. Rhodium(III) and iridium(III) pentamethylcyclopentadienyl complexes with tris(2-carboxyethyl)phosphine, properties and cytostatic activity. J. Organomet. Chem. 2016, 822, 74-79. [CrossRef]

32. Adhikari, S.; Hussain, O.; Phillips, R.M.; Kollipara, M.R. Half-sandwich $\mathrm{d}^{6}$ metal complexes comprising of 2-substituted-1,8naphthyridine ligands with unexpected bonding modes: Synthesis, structural and anti-cancer studies. J. Organomet. Chem. 2018, 854, 27-37. [CrossRef]

33. Lucas, S.J.; Lord, R.M.; Basri, A.M.; Allison, S.J.; Phillips, R.M.; Blacker, A.J.; McGowan, P.C. Increasing anti-cancer activity with longer tether lengths of group $9 \mathrm{Cp}^{*}$ complexes. Dalton Trans. 2016, 45, 6812-6815. [CrossRef] [PubMed]

34. Lord, R.M.; Holmes, J.; Singer, F.N.; Frith, A.; Willans, C.E. Precious metal N-heterocyclic carbene-carbaboranyl complexes: Cytotoxic and selective compounds for the treatment of cancer. J. Organomet. Chem. 2020, 907, 121062. [CrossRef]

35. Truong, D.; Sullivan, M.P.; Tong, K.K.H.; Steel, T.R.; Prause, A.; Lovett, J.H.; Andersen, J.W.; Jamieson, S.M.F.; Harris, H.H.; Ott, I.; et al. Potent Inhibition of Thioredoxin Reductase by the Rh Derivatives of Anticancer $\mathrm{M}\left(\operatorname{arene} / \mathrm{Cp}^{*}\right)(\mathrm{NHC}) \mathrm{Cl}_{2} \mathrm{Complexes}$. Inorg. Chem. 2020, 59, 3281-3289. [CrossRef]

36. Scharwitz, M.A.; Ott, I.; Geldmacher, Y.; Gust, R.; Sheldrick, W.S. Cytotoxic half-sandwich rhodium(III) complexes: Polypyridyl ligand influence on their DNA binding properties and cellular uptake. J. Organomet. Chem. 2008, 693, 2299-2309. [CrossRef]

37. Geldmacher, Y.; Rubbiani, R.; Wefelmeier, P.; Prokop, A.; Ott, I.; Sheldrick, W.S. Synthesis and DNA-binding properties of apoptosis-inducing cytotoxic half-sandwich rhodium(III) complexes with methyl-substituted polypyridyl ligands. J. Organomet. Chem. 2011, 696, 1023-1031. [CrossRef]

38. Soldevila-Barreda, J.J.; Habtemariam, A.; Romero-Canelón, I.; Sadler, P.J. Half-sandwich rhodium(III) transfer hydrogenation catalysts: Reduction of NAD+ and pyruvate, and antiproliferative activity. J. Inorg. Biochem. 2015, 153, 322-333. [CrossRef]

39. Cross, J.M.; Blower, T.R.; Gallagher, N.; Gill, J.H.; Rockley, K.L.; Walton, J.W. Anticancer Ru ${ }^{\mathrm{II}}$ and Rh ${ }^{\mathrm{III}}$ Piano-Stool Complexes that are Histone Deacetylase Inhibitors. ChemPlusChem 2016, 81, 1276-1280. [CrossRef] 
40. Shadap, L.; Tyagi, J.L.; Poluri, K.M.; Pinder, E.; Phillips, R.M.; Kaminsky, W.; Kollipara, M.R. Synthesis, structural and in-vitro functional studies of half-sandwich platinum group metal complexes having various bonding modes of benzhydrazone derivative ligands. Polyhedron 2020, 176, 114293. [CrossRef]

41. Soldevila-Barreda, J.J.; Fawibe, K.B.; Azmanova, M.; Rafols, L.; Pitto-Barry, A.; Eke, U.B.; Barry, N.P.E. Synthesis, Characterisation and In Vitro Anticancer Activity of Catalytically Active Indole-Based Half-Sandwich Complexes. Molecules 2020, $25,4540$. [CrossRef]

42. Kandioller, W.; Balsano, E.; Meier, S.M.; Jungwirth, U.; Göschl, S.; Roller, A.; Jakupec, M.A.; Berger, W.; Keppler, B.K.; Hartinger, C.G. Organometallic anticancer complexes of lapachol: Metal centre-dependent formation of reactive oxygen species and correlation with cytotoxicity. Chem. Commun. 2013, 49, 3348-3350. [CrossRef]

43. Pettinari, R.; Marchetti, F.; Pettinari, C.; Condello, F.; Petrini, A.; Scopelliti, R.; Riedel, T.; Dyson, P.J. Organometallic rhodium(III) and iridium(III) cyclopentadienyl complexes with curcumin and bisdemethoxycurcumin co-ligands. Dalton Trans. 2015, 44, 20523-20531. [CrossRef] [PubMed]

44. Kurzwernhart, A.; Mokesch, S.; Klapproth, E.; Adib-Ravazi, M.S.; Jakupec, M.A.; Hartinger, C.G.; Kandioller, W.; Keppler, B.K. Flavonoid-Based Organometallics with Different Metal Centers-Investigations of the Effects on Reactivity and Cytotoxicity. Eur. J. Inorg. Chem. 2016, 2016, 240-246. [CrossRef]

45. Raja, N.; Devika, N.; Gupta, G.; Nayak, V.L.; Kamal, A.; Nagesh, N.; Therrien, B. Biological activities of pyrenyl-derived thiosemicarbazone half-sandwich complexes. J. Organomet. Chem. 2015, 794, 104-114. [CrossRef]

46. Adhikari, S.; Hussain, O.; Phillips, R.M.; Kaminsky, W.; Kollipara, M.R. Synthesis, structural and chemosensitivity studies of arene d6 metal complexes having $N$-phenyl- $N^{\prime}$-(pyridyl/pyrimidyl)thiourea derivatives. Appl. Organomet. Chem. 2018, 32 , e4362. [CrossRef]

47. Tong, K.K.H.; Hanif, M.; Lovett, J.H.; Hummitzsch, K.; Harris, H.H.; Soehnel, T.; Jamieson, S.M.F.; Hartinger, C.G. Thioureaderived chelating ligands and organometallic compounds and investigations into anticancer activity. Molecules 2020, $25,3661$. [CrossRef]

48. Schmidlehner, M.; Flocke, L.S.; Roller, A.; Hejl, M.; Jakupec, M.A.; Kandioller, W.; Keppler, B.K. Cytotoxicity and preliminary mode of action studies of novel 2-aryl-4-thiopyrone-based organometallics. Dalton Trans. 2016, 45, 724-733. [CrossRef] [PubMed]

49. Hackl, C.M.; Legina, M.S.; Pichler, V.; Schmidlehner, M.; Roller, A.; Dömötör, O.; Enyedy, E.A.; Jakupec, M.A.; Kandioller, W.; Keppler, B.K. Thiomaltol-Based Organometallic Complexes with 1-Methylimidazole as Leaving Group: Synthesis, Stability, and Biological Behavior. Chem. Eur. J. 2016, 22, 17269-17281. [CrossRef]

50. Harringer, S.; Happl, B.; Ozenil, M.; Kast, C.; Hejl, M.; Wernitznig, D.; Legin, A.A.; Schweikert, A.; Gajic, N.; Roller, A.; et al Synthesis, Modification, and Biological Evaluation of a Library of Novel Water-Soluble Thiopyridone-Based Organometallic Complexes and Their Unexpected (Biological) Behavior. Chem. Eur. J. 2020, 26, 5419-5433. [CrossRef]

51. Harringer, S.; Matzinger, M.; Gajic, N.; Hejl, M.; Jakupec, M.A.; Kandioller, W.; Keppler, B.K. First insights into the novel class of organometallic compounds bearing a bidentate selenopyridone coordination motif: Synthesis, characterization, stability and biological investigations. Inorg. Chim. Acta 2020, 513, 119919. [CrossRef]

52. Ruiz, J.; Rodriguez, V.; Cutillas, N.; Samper, K.G.; Capdevila, M.; Palacios, O.; Espinosa, A. Novel C,N-chelate rhodium(III) and iridium(III) antitumor complexes incorporating a lipophilic steroidal conjugate and their interaction with DNA. Dalton Trans. 2012, 41, 12847-12856. [CrossRef]

53. Rono, C.K.; Chu, W.K.; Darkwa, J.; Meyer, D.; Makhubela, B.C.E. Triazolyl Ru ${ }^{\mathrm{II}}$, Rh ${ }^{\mathrm{III}}$, Os ${ }^{\mathrm{II}}$, and Ir $\mathrm{III}^{\mathrm{II}}$ Complexes as Potential Anticancer Agents: Synthesis, Structure Elucidation, Cytotoxicity, and DNA Model Interaction Studies. Organometallics 2019, 38, 3197-3211. [CrossRef]

54. Yellol, G.S.; Donaire, A.; Yellol, J.G.; Vasylyeva, V.; Janiak, C.; Ruiz, J. On the antitumor properties of novel cyclometalated benzimidazole $\mathrm{Ru}(\mathrm{II}), \mathrm{Ir}(\mathrm{III})$ and $\mathrm{Rh}(\mathrm{III})$ complexes. Chem. Commun. 2013, 49, 11533-11535. [CrossRef]

55. Mukhopadhyay, S.; Gupta, R.K.; Paitandi, R.P.; Rana, N.K.; Sharma, G.; Koch, B.; Rana, L.K.; Hundal, M.S.; Pandey, D.S. Synthesis, Structure, DNA/Protein Binding, and Anticancer Activity of Some Half-Sandwich Cyclometalated Rh(III) and Ir(III) Complexes. Organometallics 2015, 34, 4491-4506. [CrossRef]

56. Zhang, W.Y.; Bridgewater, H.E.; Banerjee, S.; Soldevila-Barreda, J.J.; Clarkson, G.J.; Shi, H.; Imberti, C.; Sadler, P.J. LigandControlled Reactivity and Cytotoxicity of Cyclometalated Rhodium(III) Complexes. Eur. J. Inorg. Chem. 2020, 2020, $1052-1060$. [CrossRef] [PubMed]

57. Casini, A.; Edafe, F.; Erlandsson, M.; Gonsalvi, L.; Ciancetta, A.; Re, N.; Ienco, A.; Messori, L.; Peruzzini, M.; Dyson, P.J. Rationalization of the inhibition activity of structurally related organometallic compounds against the drug target cathepsin $\mathrm{B}$ by DFT. Dalton Trans. 2010, 39, 5556-5563. [CrossRef] [PubMed]

58. Dkhar, L.; Banothu, V.; Pinder, E.; Phillips, R.M.; Kaminsky, W.; Kollipara, M.R. Ru, Rh and Ir metal complexes of pyridyl chalcone derivatives: Their potent antibacterial activity, comparable cytotoxicity potency and selectivity to cisplatin. Polyhedron 2020, 185, 114606. [CrossRef]

59. Li, Y.; de Kock, C.; Smith, P.J.; Guzgay, H.; Hendricks, D.T.; Naran, K.; Mizrahi, V.; Warner, D.F.; Chibale, K.; Smith, G.S. Synthesis, characterization, and pharmacological evaluation of silicon-containing aminoquinoline organometallic complexes as antiplasmodial, antitumor, and antimycobacterial agents. Organometallics 2013, 32, 141-150. [CrossRef] 
60. Su, W.; Li, Y.; Peng, B.; Xie, J.; Li, P.; Xiao, Q.; Huang, S. Half-sandwich $\left(\mathrm{Cp}^{*}\right) \mathrm{RhCl}_{2}$ core complexes containing sulfur donor thiosemicarbazones: Synthesis, cytotoxic activity and human serum albumin binding studies. J. Organomet. Chem. 2018, 868, 24-30. [CrossRef]

61. Adhikari, S.; Hussain, O.; Phillips, R.M.; Kaminsky, W.; Kollipara, M.R. Neutral and cationic half-sandwich arene d6 metal complexes containing pyridyl and pyrimidyl thiourea ligands with interesting bonding modes: Synthesis, structural and anti-cancer studies. Appl. Organomet. Chem. 2018, 32, e4476. [CrossRef]

62. Lapasam, A.; Hussain, O.; Phillips, R.M.; Kaminsky, W.; Kollipara, M.R. Synthesis, characterization and chemosensitivity studies of half-sandwich ruthenium, rhodium and iridium complexes containing $\mathrm{k}^{1}(\mathrm{~S})$ and $\mathrm{\kappa}^{2}(\mathrm{~N}, \mathrm{~S})$ aroylthiourea ligands. J. Organomet. Chem. 2019, 880, 272-280. [CrossRef]

63. Geldmacher, Y.; Splith, K.; Kitanovic, I.; Alborzinia, H.; Can, S.; Rubbiani, R.; Nazif, M.A.; Wefelmeier, P.; Prokop, A.; Ott, I.; et al. Cellular impact and selectivity of half-sandwich organorhodium(III) anticancer complexes and their organoiridium(III) and trichloridorhodium(III) counterparts. J. Biol. Inorg. Chem. 2012, 17, 631-646. [CrossRef] [PubMed]

64. Gupta, G.; Sharma, G.; Koch, B.; Park, S.; Lee, S.S.; Kim, J. Syntheses, characterization and molecular structures of novel Ru(II), $\mathrm{Rh}(\mathrm{III})$ and Ir(III) complexes and their possible roles as antitumour and cytotoxic agents. New J. Chem. 2013, 37, $2573-2581$. [CrossRef]

65. Liu, Z.; Habtemariam, A.; Pizarro, A.M.; Fletcher, S.A.; Kisova, A.; Vrana, O.; Salassa, L.; Bruijnincx, P.C.A.; Clarkson, G.J.; Brabec, V.; et al. Organometallic half-sandwich iridium anticancer complexes. J. Med. Chem. 2011, 54, 3011-3026. [CrossRef]

66. Matsheku, A.C.; Chen, M.Y.H.; Jordaan, S.; Prince, S.; Smith, G.S.; Makhubela, B.C.E. Acridine-containing Ru ${ }^{\mathrm{II}}$, Os ${ }^{\mathrm{II}}$, Rh $\mathrm{Rh}^{\mathrm{III}}$ and IrII Half-Sandwich Complexes: Synthesis, Structure and Antiproliferative Activity. Appl. Organomet. Chem. 2017, 31 , e3852. [CrossRef]

67. Gras, M.; Therrien, B.; Suss-Fink, G.; Casini, A.; Edafe, F.; Dyson, P.J. Anticancer activity of new organo-ruthenium, rhodium and iridium complexes containing the 2-(pyridine-2-yl)thiazole N,N-chelating ligand. J. Organomet. Chem. 2010, 695, 1119-1125. [CrossRef]

68. Gupta, R.K.; Pandey, R.; Sharma, G.; Prasad, R.; Koch, B.; Srikrishna, S.; Li, P.Z.; Xu, Q.; Pandey, D.S. DNA Binding and Anti-Cancer Activity of Redox-Active Heteroleptic Piano-Stool Ru(II), Rh(III), and Ir(III) Complexes Containing 4-(2Methoxypyridyl)phenyldipyrromethene. Inorg. Chem. 2013, 52, 3687-3698. [CrossRef] [PubMed]

69. Gupta, R.K.; Sharma, G.; Pandey, R.; Kumar, A.; Koch, B.; Li, P.Z.; Xu, Q.; Pandey, D.S. DNA/Protein Binding, Molecular Docking, and in Vitro Anticancer Activity of Some Thioether-Dipyrrinato Complexes. Inorg. Chem. 2013, 52, 13984-13996. [CrossRef] [PubMed]

70. Payne, R.; Govender, P.; Therrien, B.; Clavel, C.M.; Dyson, P.J.; Smith, G.S. Neutral and cationic multinuclear half-sandwich rhodium and iridium complexes coordinated to poly(propyleneimine) dendritic scaffolds: Synthesis and cytotoxicity. J. Organomet. Chem. 2013, 729, 20-27. [CrossRef]

71. Almodares, Z.; Lucas, S.J.; Crossley, B.D.; Basri, A.M.; Pask, C.M.; Hebden, A.J.; Phillips, R.M.; McGowan, P.C. Rhodium, Iridium, and Ruthenium Half-Sandwich Picolinamide Complexes as Anticancer Agents. Inorg. Chem. 2014, 53, 727-736. [CrossRef]

72. Kalidasan, M.; Forbes, S.; Mozharivskyj, Y.; Ahmadi, M.; Ahmadihosseini, Z.; Phillips, R.M.; Kollipara, M.R. Mononuclear halfsandwich cyclic-p-perimeter platinum group metal complexes having bithiazole ligands: Synthesis, molecular and anti-cancer studies. Inorg. Chim. Acta 2014, 421, 349-358. [CrossRef]

73. Palepu, N.R.; Nongbri, S.L.; Premkumar, J.R.; Verma, A.K.; Bhattacharjee, K.; Joshi, S.R.; Forbes, S.; Mozharivskyj, Y.; Thounaojam, R.; Aguan, K.; et al. Synthesis and evaluation of new salicylaldehyde-2-picolinylhydrazone Schiff base compounds of Ru(II), $\mathrm{Rh}(\mathrm{III})$ and $\mathrm{Ir}(\mathrm{III})$ as in vitro antitumor, antibacterial and fluorescence imaging agents. J. Biol. Inorg. Chem. 2015, 20, 619-638. [CrossRef]

74. Kumar, A.; Kumar, A.; Gupta, R.K.; Paitandi, R.P.; Singh, K.B.; Trigun, S.K.; Hundal, M.S.; Pandey, D.S. Cationic Ru(II), Rh(III) and $\operatorname{Ir}(\mathrm{III})$ complexes containing cyclic p-perimeter and 2-aminophenyl benzimidazole ligands: Synthesis, molecular structure, DNA and protein binding, cytotoxicity and anticancer activity. J. Organomet. Chem. 2016, 801, 68-79. [CrossRef]

75. Thangavel, S.; Paulpandi, M.; Friedrich, H.B.; Murugan, K.; Kalva, S.; Skelton, A.A. Synthesis, characterization, antiproliferative and molecular docking study of new half sandwich $\mathrm{Ir}(\mathrm{III}), \mathrm{Rh}(\mathrm{III})$ and $\mathrm{Ru}(\mathrm{II})$ complexes. J. Inorg. Biochem. 2016, $159,50-61$. [CrossRef] [PubMed]

76. Adhikari, S.; Palepu, N.R.; Sutradhar, D.; Shepherd, S.L.; Phillips, R.M.; Kaminsky, W.; Chandra, A.K.; Kollipara, M.R. Neutral and cationic half-sandwich arene ruthenium, $\mathrm{Cp}^{*} \mathrm{Rh}$ and $\mathrm{C} \mathrm{p}^{*} \mathrm{Ir}$ oximato and oxime complexes: Synthesis, structural, DFT and biological studies. J. Organomet. Chem. 2016, 820, 70-81. [CrossRef]

77. Adhikari, S.; Sutradhar, D.; Shepherd, S.L.; Phillips, R.M.; Chandra, A.K.; Kollipara, M.R. Synthesis, structural, DFT calculations and biological studies of rhodium and iridium complexes containing azine Schiff-base ligands. Polyhedron 2016, 117, 404-414. [CrossRef]

78. Deo, C.; Wang, H.; Bogliotti, N.; Zang, Y.; Retailleau, P.; He, X.P.; Li, J.; Xie, J. Photoswitchable arene ruthenium and pentamethylcyclopentadienyl rhodium complexes containing osulfonamide azobenzene ligands: Synthesis, characterization and cytotoxicity. J. Organomet. Chem. 2016, 820, 111-119. [CrossRef]

79. Palepu, N.R.; Adhikari, S.; Premkumar, R.J.; Verma, A.K.; Shepherd, S.L.; Phillips, R.M.; Kaminsky, W.; Kollipara, M.R. Halfsandwich ruthenium, rhodium and iridium complexes featuring oxime ligands: Structural studies and preliminary investigation of in vitro and in vivo anti-tumour activities. Appl. Organomet. Chem. 2017, 31, e3640. [CrossRef] 
80. Palepu, N.R.; Premkumar, R.J.; Verma, A.K.; Bhattacharjee, K.; Joshi, S.R.; Forbes, S.; Mozharivskyj, Y.; Kollipara, M.R. Antibacterial, in vitro antitumor activity and structural studies of rhodium and iridium complexes featuring the two positional isomers of pyridine carbaldehyde picolinic hydrazone ligand. Arab. J. Chem. 2018, 11,714-728. [CrossRef]

81. Štarha, P.; Dvořák, Z.; Trávníček, Z. Half-sandwich Ir(III) and Rh(III) 2,2'-dipyridylamine complexes: Synthesis, characterization and in vitro cytotoxicity against the ovarian carcinoma cells. J. Organomet. Chem. 2018, 872, 114-122. [CrossRef]

82. Gilewska, A.; Barszcz, B.; Masternak, J.; Kazimierczuk, K.; Sitkowski, J.; Wietrzyk, J.; Turlej, E. Similarities and differences in $\mathrm{d}^{6}$ low-spin ruthenium, rhodium and iridium half-sandwich complexes: Synthesis, structure, cytotoxicity and interaction with biological targets. J. Biol. Inorg. Chem. 2019, 24, 591-606. [CrossRef]

83. Lapasam, A.; Pinder, E.; Phillips, R.M.; Kaminsky, W.; Kollipara, M.R. Synthesis, structure and bonding modes of pyrazine based ligands of $\mathrm{Cp}^{*} \mathrm{Rh}$ and $\mathrm{Cp} \mathrm{p}^{*} \mathrm{Ir}$ complexes: The study of in-vitro cytotoxicity against human cell lines. J. Organomet. Chem. 2019, 899, 120887. [CrossRef]

84. Sliwinska, U.; Pruchnik, F.P.; Ulaszewski, S.; Latocha, M.; Nawrocka-Musial, D. Properties of $\eta^{5}$-pentamethylcyclopentadienyl rhodium(III) and iridium(III) complexes with quinolin-8-ol and their cytostatic activity. Polyhedron 2010, 29, 1653-1659. [CrossRef]

85. Dömötör, O.; Pape, V.F.S.; May, N.V.; Szakacs, G.; Enyedy, E.A. Comparative solution equilibrium studies of antitumor ruthenium $\left(\eta^{6}-p\right.$-cymene $)$ and rhodium $\left(\eta^{5}-\mathrm{C}_{5} \mathrm{Me}_{5}\right)$ complexes of 8-hydroxyquinolines. Dalton Trans. 2017, 46, 4382-4396. [CrossRef]

86. Wirth, S.; Rohbogner, C.J.; Cieslak, M.; Kazmierczak-Baranska, J.; Donevski, S.; Nawrot, B.; Lorenz, I.P. Rhodium(III) and iridium(III) complexes with 1,2-naphthoquinone-1-oximate as a bidentate ligand: Synthesis, structure, and biological activity. J. Biol. Inorg. Chem. 2010, 15, 429-440. [CrossRef] [PubMed]

87. Enyedy, E.A.; Dömötör, O.; Hackl, C.M.; Roller, A.; Novak, M.S.; Jakupec, M.A.; Keppler, B.K.; Kandioller, W. Solution equilibria and antitumor activities of pentamethylcyclopentadienyl rhodium complexes of picolinic acid and deferiprone. J. Coord. Chem. 2015, 68, 1583-1601. [CrossRef]

88. Burgoyne, A.R.; Kaschula, C.H.; Parker, M.I.; Smith, G.S. Synthesis and anticancer evaluation of mono- and trinuclear halfsandwich rhodium(III) and iridium(III) complexes based on $\mathrm{N}, \mathrm{O}$-salicylaldiminato-sulfonated scaffolds. J. Organomet. Chem. 2017, 846, 100-104. [CrossRef]

89. Dömötör, O.; Hackl, C.M.; Bali, K.; Roller, A.; Hejl, M.; Jakupec, M.A.; Keppler, B.K.; Kandioller, W.; Enyedy, E.A. Comparative equilibrium and structural studies of new pentamethylcyclopentadienyl rhodium complexes bearing $(\mathrm{O}, \mathrm{N})$ donor bidentate ligands. J. Organomet. Chem. 2017, 846, 287-295. [CrossRef]

90. Markham, J.; Liang, J.; Levina, A.; Mak, R.; Johannessen, B.; Kappen, P.; Glover, C.J.; Lai, B.; Vogt, S.; Lay, P.A. (Pentamethylcyclopentadienato)rhodium Complexes for Delivery of the Curcumin Anticancer Drug. Eur. J. Inorg. Chem. 2017, $2017,1812-1823$. [CrossRef]

91. Meszaros, J.P.; Poljarevic, J.M.; Gal, G.T.; May, N.V.; Spengler, G.; Enyedy, E.A. Comparative solution and structural studies of half-sandwich rhodium and ruthenium complexes bearing curcumin and acetylacetone. J. Inorg. Biochem. 2019, 195, 91-100. [CrossRef]

92. Su, W.; Wang, X.; Lei, X.; Xiao, Q.; Huang, S.; Li, P. Synthesis, characterization, cytotoxic activity of half-sandwich rhodium(III), and iridium(III) complexes with curcuminoids. J. Organomet. Chem. 2017, 833, 54-60. [CrossRef]

93. Mokesch, S.; Novak, M.S.; Roller, A.; Jakupec, M.A.; Kandioller, W.; Keppler, B.K. 1,3-Dioxoindane-2-carboxamides as bioactive ligand scaffolds for the development of novel organometallic anticancer drugs. Organometallics 2015, 34, 848-857. [CrossRef]

94. Domotor, O.; Aicher, S.; Schmidlehner, M.; Novak, M.S.; Roller, A.; Jakupec, M.A.; Kandioller, W.; Hartinger, C.G.; Keppler, B.K.; Enyedy, E.A. Antitumor pentamethylcyclopentadienyl rhodium complexes of maltol and allomaltol: Synthesis, solution speciation and bioactivity. J. Inorg. Biochem. 2014, 134, 57-65. [CrossRef] [PubMed]

95. Schmidlehner, M.; Pichler, V.; Roller, A.; Jakupec, M.A.; Kandioller, W.; Keppler, B.K. Organometallic complexes of (thio)allomaltolbased Mannich-products: Synthesis, stability and preliminary biological investigations. J. Organomet. Chem. 2015, 782, 69-76. [CrossRef]

96. Petrini, A.; Pettinari, R.; Marchetti, F.; Pettinari, C.; Therrien, B.; Galindo, A.; Scopelliti, R.; Riedel, T.; Dyson, P.J. Cytotoxic Half-Sandwich Rh(III) and Ir(III) b-Diketonates. Inorg. Chem. 2017, 56, 13600-13612. [CrossRef]

97. Meszaros, J.P.; Geisler, H.; Poljarevic, J.M.; Roller, A.; Legina, M.S.; Hejl, M.; Jakupec, M.A.; Keppler, B.K.; Kandioller, W.; Enyedy, E.A. Naphthoquinones of natural origin: Aqueous chemistry and coordination to half-sandwich organometallic cations. $J$. Organomet. Chem. 2020, 907, 121070. [CrossRef]

98. Su, W.; Luo, Z.; Dong, S.; Chen, X.; Xiao, J.; Peng, B.; Li, P. Novel half-sandwich rhodium(III) and iridium(III) photosensitizers for dual chemo- and photodynamic therapy. Photodiagn. Photodyn. Ther. 2019, 26, 448-454. [CrossRef] [PubMed]

99. Hackl, C.M.; Schoenhacker-Alte, B.; Klose, M.H.M.; Henke, H.; Legina, M.S.; Jakupec, M.A.; Berger, W.; Keppler, B.K.; Bruggemann, O.; Teasdale, I.; et al. Synthesis and in vivo anticancer evaluation of poly(organo)phosphazene-based metallodrug conjugates. Dalton Trans. 2017, 46, 12114-12124. [CrossRef]

100. Aradhyula, B.P.R.; Kalidasan, M.; Gangele, K.; Deb, D.K.; Shepherd, S.L.; Phillips, R.M.; Poluri, K.M.; Kollipara, M.R. Synthesis, Structural and Biological Studies of Some Half-Sandwich d6-Metal Complexes with Pyrimidine-Based Ligands. ChemistrySelect 2017, 2, 2065-2076. [CrossRef]

101. Burgoyne, A.R.; Kaschula, C.H.; Parker, M.I.; Smith, G.S. Tripodal Half-Sandwich Rhodium and Iridium Complexes Containing Sulfonate and Pyridinyl Entities as Antitumor Agents. Eur. J. Inorg. Chem. 2017, 2017, 5379-5386. [CrossRef] 
102. Tremlett, W.D.J.; Tong, K.K.H.; Steel, T.R.; Movassaghi, S.; Hanif, M.; Jamieson, S.M.F.; Sohnel, T.; Hartinger, C.G. Hydroxyquinoline-derived anticancer organometallics: Introduction of amphiphilic PTA as an ancillary ligand increases their aqueous solubility. J. Inorg. Biochem. 2019, 199, 110768. [CrossRef]

103. Patalenszki, J.; Biro, L.; Benyei, A.C.; Radosova-Muchova, T.; Kasparkova, J.; Buglyo, P. Half-sandwich complexes of ruthenium, osmium, rhodium and iridium with DL-methionine or S-methyl-L-cysteine: A solid state and solution equilibrium study. RSC Adv. 2015, 5, 8094-8107. [CrossRef]

104. Aboura, W.; Batchelor, L.K.; Garci, A.; Dyson, P.J.; Therrien, B. Reactivity and biological activity of N,N,S-Schiff-base rhodium pentamethylcyclopentadienyl complexes. Inorg. Chim. Acta 2020, 501, 119265. [CrossRef]

105. Amouri, H.; Moussa, J.; Renfrew, A.K.; Dyson, P.J.; Rager, M.N.; Chamoreau, L.M. Discovery, Structure, and Anticancer Activity of an Iridium Complex of Diselenobenzoquinone. Angew. Chem. Int. Ed. 2010, 49, 7530-7533. [CrossRef]

106. Rubner, G.; Bensdorf, K.; Wellner, A.; Bergemann, S.; Ott, I.; Gust, R. [Cyclopentadienyl]metalcarbonyl complexes of acetylsalicylic acid as neo-anticancer agents. Eur. J. Med. Chem. 2010, 45, 5157-5163. [CrossRef]

107. Parveen, S.; Hanif, M.; Leung, E.; Tong, K.K.H.; Yang, A.; Astin, J.; De Zoysa, G.H.; Steel, T.R.; Goodman, D.; Movassaghi, S.; et al. Anticancer organorhodium and -iridium complexes with low toxicity in vivo but high potency in vitro: DNA damage, reactive oxygen species formation, and haemolytic activity. Chem. Commun. 2019, 55, 12016-12019. [CrossRef] [PubMed]

108. Gupta, G.; Kumar, J.M.; Garci, A.; Rangaraj, N.; Nagesh, N.; Therrien, B. Anticancer Activity of Half-Sandwich Rh(III) and Ir(III) Metalla-Prisms Containing Lipophilic Side Chains. ChemPlusChem 2014, 79, 610-618. [CrossRef] [PubMed]

109. Gupta, G.; Garci, A.; Murray, B.S.; Dyson, P.J.; Fabre, G.; Trouillas, P.; Giannini, F.; Furrer, J.; Suss-Fink, G.; Therrien, B. Synthesis, molecular structure, computational study and in vitro anticancer activity of dinuclear thiolatobridged pentamethylcyclopentadienyl Rh(III) and Ir(III) complexes. Dalton Trans. 2013, 42, 15457-15463. [CrossRef] [PubMed]

110. Gupta, G.; Kumar, J.M.; Garci, A.; Nagesh, N.; Therrien, B. Exploiting natural products to build metalla-assemblies: The anticancer activity of embelin-derived $\mathrm{Rh}(\mathrm{III})$ and Ir(III) metalla-rectangles. Molecules 2014, 19, 6031-6046. [CrossRef] [PubMed]

111. Gupta, G.; Oggu, G.S.; Nagesh, N.; Bokara, K.K.; Therrien, B. Anticancer activity of large metalla-assemblies built from halfsandwich complexes. CrystEngComm 2016, 18, 4952-4957. [CrossRef]

112. Govender, P.; Riedel, T.; Dyson, P.J.; Smith, G.S. Regulating the anticancer properties of organometallic dendrimers using pyridylferrocene entities: Synthesis, cytotoxicity and DNA binding studies. Dalton Trans. 2016, 45, 9529-9539. [CrossRef]

113. Wenzel, M.; de Almeida, A.; Bigaeva, E.; Kavanagh, P.; Picquet, M.; Le Gendre, P.; Bodio, E.; Casini, A. New Luminescent Polynuclear Metal Complexes with Anticancer Properties: Toward Structure-Activity Relationships. Inorg. Chem. 2016, 55, 2544-2557. [CrossRef]

114. Chellan, P.; Land, K.M.; Shokar, A.; Au, A.; An, S.H.; Taylor, D.; Smith, P.J.; Riedel, T.; Dyson, P.J.; Chibale, K.; et al. Synthesis and evaluation of new polynuclear organometallic $\mathrm{Ru}(\mathrm{II}), \mathrm{Rh}(\mathrm{III})$ and $\mathrm{Ir}(\mathrm{III})$ pyridyl ester complexes as in vitro antiparasitic and antitumor agents. Dalton Trans. 2014, 43, 513-526. [CrossRef]

115. Burgoyne, A.R.; Kaschula, C.H.; Parker, M.I.; Smith, G.S. In vitro Cytotoxicity of Half-Sandwich Platinum Group Metal Complexes of a Cationic Alkylated Phosphaadamantane Ligand. Eur. J. Inorg. Chem. 2016, 2016, 1267-1273. [CrossRef]

116. Rao, A.B.P.; Uma, A.; Chiranjeevi, T.; Bethu, M.S.; Rao, J.V.; Deb, D.K.; Sarkar, B.; Kaminsky, W.; Kollipara, M.R. The in vitro antitumor activity of oligonuclear polypyridyl rhodium and iridium complexes against cancer cells and human pathogens. $J$. Organomet. Chem. 2016, 824, 131-139. [CrossRef]

117. Sudding, L.C.; Payne, R.; Govender, P.; Edafe, F.; Clavel, C.M.; Dyson, P.J.; Therrien, B.; Smith, G.S. Evaluation of the in vitro anticancer activity of cyclometalated half-sandwich rhodium and iridium complexes coordinated to naphthaldimine-based poly(propyleneimine) dendritic scaffolds. J. Organomet. Chem. 2014, 774, 79-85. [CrossRef]

118. Burgoyne, A.R.; Makhubela, B.C.E.; Meyer, M.; Smith, G.S. Trinuclear Half-Sandwich RuII, RhIII and IrIII Polyester Organometallic Complexes: Synthesis and in vitro Evaluation as Antitumor Agents. Eur. J. Inorg. Chem. 2015, 2015, 1433-1444. [CrossRef]

119. Furrer, J.; Süss-Fink, G. Thiolato-bridged dinuclear arene ruthenium complexes and their potential as anticancer drugs. Coord. Chem. Rev. 2016, 309, 36-50. [CrossRef]

120. Johnpeter, J.P.; Gupta, G.; Kumar, J.M.; Srinivas, G.; Nagesh, N.; Therrien, B. Biological Studies of Chalcogenolato-Bridged Dinuclear Half-Sandwich Complexes. Inorg. Chem. 2013, 52, 13663-13673. [CrossRef] [PubMed]

121. Gupta, G.; Murray, B.S.; Dyson, P.J.; Therrien, B. Highly cytotoxic trithiolato-bridged dinuclear Rh(III) and Ir(III) complexes. J. Organomet. Chem. 2014, 767, 78-82. [CrossRef]

122. Gupta, G.; Murray, B.S.; Dyson, P.J.; Therrien, B. Synthesis, Molecular Structure and Cytotoxicity of Molecular Materials Based on Water Soluble Half-Sandwich Rh(III) and Ir(III) Tetranuclear Metalla-Cycles. Materials 2013, 6, 5352-5366. [CrossRef] [PubMed]

123. Gupta, G.; Denoyelle-Di-Muro, E.; Mbakidi, J.P.; Leroy-Lhez, S.; Sol, V.; Therrien, B. Delivery of porphin to cancer cells by organometallic Rh(III) and Ir(III) metalla-cages. J. Organomet. Chem. 2015, 787, 44-50. [CrossRef]

124. Van Niekerk, A.; Chellan, P.; Mapolie, S.F. Heterometallic Multinuclear Complexes as Anti-Cancer Agents-An Overview of Recent Developments. Eur. J. Inorg. Chem. 2019, 2019, 3432-3455. [CrossRef]

125. Nkoana, W.; Nyoni, D.; Chellan, P.; Stringer, T.; Taylor, D.; Smith, P.J.; Hutton, A.T.; Smith, G.S. Heterometallic half-sandwich complexes containing a ferrocenyl motif: Synthesis, molecular structure, electrochemistry and antiplasmodial evaluation. J. Organomet. Chem. 2014, 752, 67-75. [CrossRef] 
126. Paitandi, R.P.; Gupta, R.K.; Singh, R.S.; Sharma, G.; Koch, B.; Pandey, D.S. Interaction of ferrocene appended Ru(II), Rh(III) and Ir(III) dipyrrinato complexes with DNA/protein, molecular docking and antitumor activity. Eur. J. Med. Chem. 2014, 84, 17-29. [CrossRef] [PubMed]

127. Cassells, I.; Stringer, T.; Hutton, A.T.; Prince, S.; Smith, G.S. Impact of various lipophilic substituents on ruthenium(II), rhodium(III) and iridium(III) salicylaldimine-based complexes: Synthesis, in vitro cytotoxicity studies and DNA interactions. J. Biol. Inorg. Chem. 2018, 23, 763-774. [CrossRef] [PubMed]

128. Askari, B.; Rudbari, H.A.; Micale, N.; Schirmeister, T.; Maugeri, A.; Navarra, M. Anticancer study of heterobimetallic platinum(II)ruthenium(II) and platinum(II)-rhodium(III) complexes with bridging dithiooxamide ligand. J. Organomet. Chem. 2019, 900, 120918. [CrossRef]

129. Steckhan, E.; Herrmann, S.; Ruppert, R.; Dietz, E.; Frede, M.; Spika, E. Analytical Study of a Series of Substituted (2,2'-Bipyridyl) (Pentamethylcyclopentadienyl) Rhodium and -Iridium Complexes with Regard to Their Effectiveness as Redox Catalysts for the Indirect Electrochemical and Chemical Reduction of NAD(P)+. Organometallics 1991, 10, 1568-1577. [CrossRef]

130. Buriez, O.; Kerr, J.; Fish, R. Regioselective reduction of NAD+ models with $[\mathrm{Cp} * \mathrm{Rh}(\mathrm{Bpy}) \mathrm{H}]+$ : Structure-activity relationships and mechanistic aspects in the formation of the 1,4-NADH derivatives. Angew. Chem. Int. Ed. 1999, 38, 1997-2000. [CrossRef]

131. Canivet, J.; Süss-Fink, G.; Štěpnička, P. Water-soluble phenanthroline complexes of rhodium, iridium and ruthenium for the regeneration of $\mathrm{NADH}$ in the enzymatic reduction of ketones. Eur. J. Inorg. Chem. 2007, 2007, 4736-4742. [CrossRef]

132. Betanzos-Lara, S.; Liu, Z.; Habtemariam, A.; Pizarro, A.M.; Qamar, B.; Sadler, P.J. Organometallic Ruthenium and Iridium Transfer-Hydrogenation Catalysts Using Coenzyme NADH as a Cofactor. Angew. Chem. Int. Ed. 2012, 51, 3897-3900. [CrossRef]

133. Coverdale, J.P.C.; Romero-Canelón, I.; Sanchez-Cano, C.; Clarkson, G.J.; Habtemariam, A.; Wills, M.; Sadler, P.J. Asymmetric Transfer Hydrogenation by Synthetic Catalysts in Cancer Cells. Nat. Chem. 2018, 10, 347-354. [CrossRef] [PubMed]

134. Soldevila-Barreda, J.J.; Romero-Canelón, I.; Habtemariam, A.; Sadler, P.J. Transfer hydrogenation catalysis in cells as a new approach to anticancer drug design. Nat. Commun. 2015, 6, 6582. [CrossRef] [PubMed] 